\title{
Mitä 1960-luvulla tapahtuu keskikoulunsa päättäneille
}

Eräitä ennakkotietoja suomalaisesta lukiotutkimuksesta

\section{ANNA-LIISA SYSIHARJU}

Helsingin yliopiston kasvatustieteen laitos

Peruskoulu-uudistuksen suunnittelun rinnalla on nuorisoasteen koulutusta ja erityisesti lukion uudistamista koskeva keskustelu jatkuvasti vireytymässä. Sekä peruskoulun toteuttamista että lukioasteen koulutuksen uudelleenjärjestelyä koskevassa työssä saattaa olla hyötyä tutustumisesta siihen kuvaan, joka on hahmottumassa nykyisistä keskikouluaan päättävistä nuorista ja heidän elämänvaiheistaan sen jälkeen ns. "Lukiotutkimuksen" puitteissa. Siksi seuraavassa esitelläänkin eräitä tässä tutkimuksessa tehtyjä havaintoja siitä huolimatta, että työn aineistonkeräyskin vielä on kesken.

\section{Lukiotutkimuksen tausta ja tutkitut koulut}

"Lukiotutkimus» on saanut alkunsa Pohjoismaisen kulttuuritoimikunnan ja Pedagogien pohjoismaisen yhteistyötoimikunnan aloitteesta, jossa suositeltiin Pohjoismaiden välistä tutkimusyhteistyötä lukioon siirtymistä ja lukionkäyntiä koskevissa ongelmissa. Suomessa on allekirjoittanut suorittanut Helsingin yliopiston kasvatustieteen laitoksella tätä tutkimusta, jota valvoo opetusministeriön 1964 asettama lukiotutkimustoimikunta. Pohjoismainen yhteistyö on ilmennyt toisaalta "Pedagogisk Forskning»-lehdessä 1966 julkaistuissa kunkin pohjoismaan nykyistä lukionkäyntiä koskevissa katsauksissa, jotka 1967 julkaistiin englanninkielisen vertailevan katsauksen kera erillisenä kirjana (Veien til og gjennom gymnaset i de nordiske land, toim. Sandven ja Sysiharju, Universitetsforlaget, Oslo). Toisaalta kussakin pohjoismaassa käynnissä olevan lukiotutkimuksen edustajat ovat vuosittain neuvotelleet.

Vaikka eri pohjoismaiden lukiotutkimuksilla onkin kunkin maan ajankohtaisista ongelmista ja tutkijoiden kysymyksenasetteluista johtuvia erilaisia piirteitä, niille kaikille on kuitenkin yhteistä se, että tutkimuksessa pyritään seuraamaan määrätyn keskikoulusta lukioon siirtyvän oppilasryhmän vaiheita ja näihin vaiheisiin liittyviä erilaisia tekijöitä. Ne ovat täten luonteeltaan paneeli- tai kohorttityyppisiä pitkittäistutkimuksia. 
Nimenomaan Suomen lukiotutkimuksessa pyritään selvittämään: 1) erilaisten sosiaalisten ja sosiaalipsykologisten ympäristötekijöiden liittymistä yksilön päätöksiin ja vaiheisiin siinä tapahtumasarjassa, joka vie hänet joko lukioon ja lukion läpi tai lukiosta pois, 2) sitä, millaisena eri yksilöt kokevat nykyisen lukion tai sen vaihtoehdot sekä 3) yksilöissä itsessään, erityisesti heidän koulumenestyksessään, tapahtuvia muutoksia lukioaikana. Tällainen tieto näyttäisi tarpeelliselta laadittaessa uudistussuunnitelmia, jotka koskevat sekä lukion osuutta nuorisoasteen koko koulutuksessa, lukion opintojen järjestelyä ja lukion oppilasvalintaa että myös yksityisiin oppilaihin kohdistuvaa opastus- ja neuvontatyötä. Suomen lukionkäynnissä 1950- ja 1960-luvuilla tapahtuneista muutoksista ja lukionkäynnin ongelmista yleensä on Kasvatusopillisessa Aikakauskirjassa 1966 julkaistu laaja katsausartikkeli "Kenestä tulee ylioppilas” (Sysiharju 1966 a).

Varsinainen empiirinen aineistokeräys Suomen lukiotutkimusta varten aloitettiin lukuvuonna 1964/65, jolloin päätettiin lähteä seuraamaan 13 oppikoulussa silloin keskikoulun viimeisellä (viidennellä) luokalla olevien oppilaiden vaiheita edelleen. Tutkimuksen kohteeksi valitusta 1435 henkilön suuruisesta ryhmästä on tähän saakka jatkuvasti kerätty tietoja kolmen koululukuvuoden $(1964 / 65,1965 / 66$ ja 1966/67) aikana käyttäen lähinnä neljää keräämistapaa: a) tutkimushenkilöille itselleen kouluissa ilman opettajia annetut (tutkijan henkilökohtaisesti esittämät ja takaisin keräämät) tai heille postitetut kyselylomakkeet, b) koulujen vuosikertomuksista ja kanslioista saatavat viralliset tiedot, c) ammatinvalinnan ohjaukselta saatavissa olevat tiedot ja d) opettajien lausunnot. Tutkimuksessa on pyritty jatkuvasti seuraamaan alkuperäisiä tutkimushenkilöitä riippumatta siitä, ovatko he siirtyneet lukioon vai ei, tai ovatko he pysyneet samassa koulussa tai vaihtaneet sitä. Päähuomio on kuitenkin kohdistunut samoissa oppikouluissa jatkuvasti opiskeleviin alkuperäisiin tutkimushenkilöihin, joista viivytyksittä edistyvät tulevat osallistumaan ylioppilaskirjoituksiin keväällä 1968. Tutkimuksen piiriin on lisähenkilöinä liitetty näiden kanssa samoille luokille myöhemmin tulleet henkilöt, jotta yhtaikaa lukiossa opiskelevista saataisiin kokonaiskuva.

Tämänlaatuinen laaja aineisto tarjoaa mahdollisuuksia monenlaisiin analyyseihin, jotka ovat vasta alullaan. Ensimmäiset empiiristä työtä koskevat selvitykset ilmestyvät englanninkielisinä osaraportteina Helsingin Yliopiston kasvatustieteen laitoksen monistesarjassa (Sysiharju 1967 a, b).

Tässä artikkelissa hahmottelen ensin nykyisistä keskikouluaan päättävistä eräitä piirteitä, joiden tunteminen tarjonnee pohjaa sekä peruskoulun että lukion uudistamista koskevalle keskustelulle. Toisaalta esittelen, millaiseksi tällaisen keskikoulua päättävän nuorisojoukon seuraavat vaiheet näyttävät yksilötasolla muodostuvan 1960-luvulla vallitsevassa koulutilanteessa. 
Taulukko 1. Tutkimuskoulujen sijaintikuntia kuvaavia tilastollisia piirteitä

Table

1. Characteristics of the communes wherein the Project Schools are located

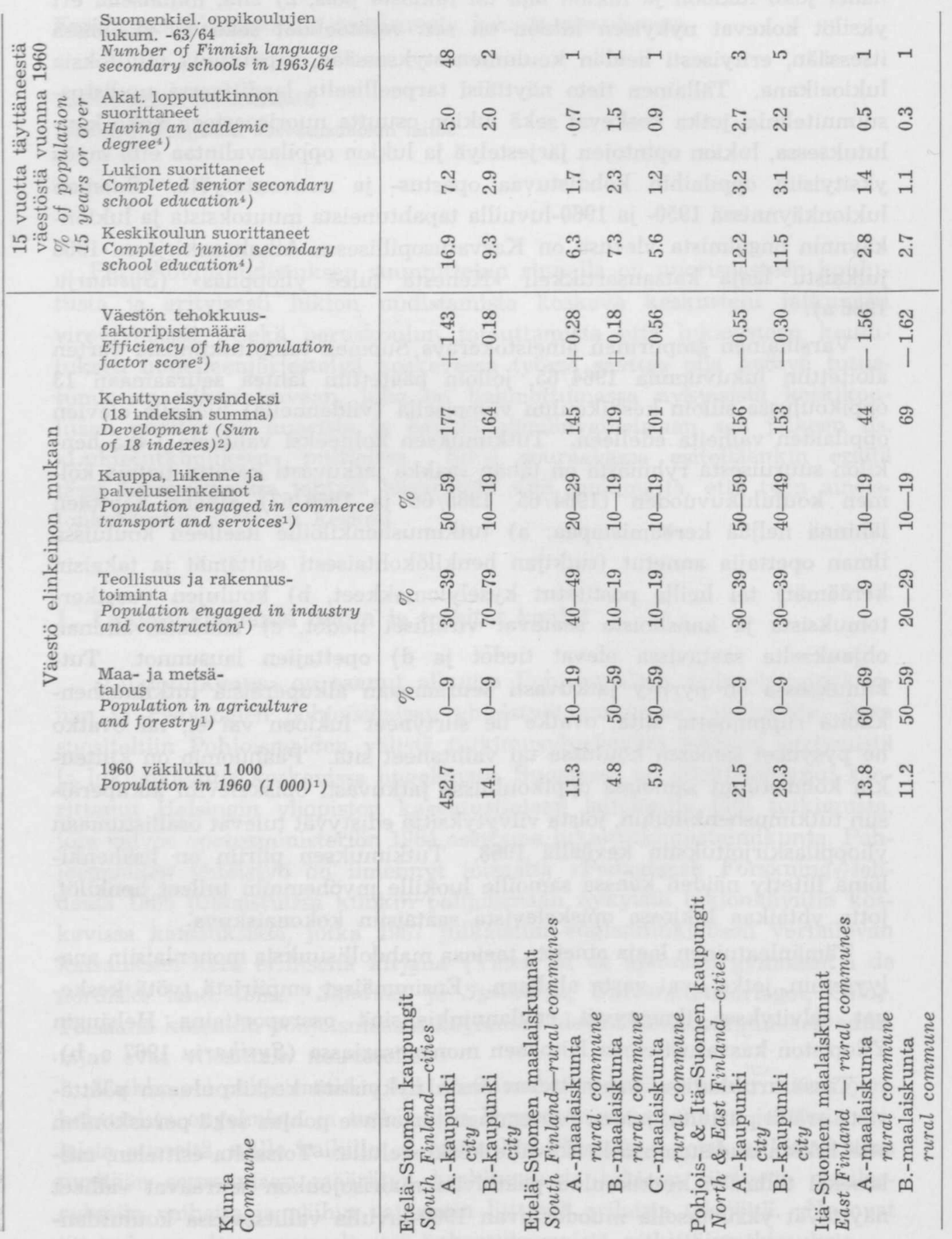


Aluksi kuitenkin selvitys tutkitun henkilöjoukon valinnasta. Kun tehtiin päätös tutkimuksen aloittamisesta lukuvuonna 1964/65 keskikoulun viidennellä luokalla olevien keskuudessa, oli todettavissa, että nämä tavallisinta "normaalia» oppikoulunkäyntiä ajatellen (7-vuotiaana kansakouluun, 4 vuoden kuluttua oppikouluun) kuuluisivat vuoden 1949 ikäluokkaan, siis vielä ns. "suuriin» yli 95000 syntynyttä käsittäneihin. Vuoden 1960 väestönlaskennassa oli näitä silloin 11-vuotiaita 96977 henkeä (Väestönlaskenta 1960 II). Samana vuonna 1960 pyrki (kouluhallituksen antamien tietojen mukaan) 57636 lasta eli $59.5 \%$ yksitoistavuotiaita vastaavasta määrästä oppikouluun ja 37835 eli $39.0 \%$ vastaava määrä otettiin. Viiden vuoden kuluttua eli lukuvuonna 1964/65 oli keskikoulun viidennellä luokalla 39170 oppilasta eli $40.5 \%$ »normaali-ikäluokasta» vastaava määrä. (Lukumäärän kasvu lienee pääasiallisesti aiheutunut luokallejäämisestä, minkä runsauteen kirjoituksessa vielä palaan). Kun tutkimus oli päätetty rajoittaa koskemaan vain suomenkielisiä oppikouluja, supistui kyseessä olevien viidesluokkalaisten määrä 36416 :een ja oppikoulujen luku 524.

Suomen lukiotutkimuksessa pidettiin tärkeänä erilaisten koulu- ja kehitysympäristöjen vertailua ja siksi päädyttiin valitsemaan tutkittavat henkilöt tästä joukosta ottamalla harkintanäytteeksi ryhmä erilaisissa ympäristöissä (Etelä-Suomi ja Pohjois-Itä-Suomi, kaupunki ja maalaiskunta) työskenteleviä oppikouluja ja kohdistamalla tutkimus näiden koulujen kaikkiin keskikouluaan päättäviin oppilaihin. Tällä tavoin valittiin yhdeksän kuntaa (neljä kaupunki ja viisi maalaiskuntaa), joiden tilastollisesti mitattavia ominaisuuksia on kuvattu taulukossa 1.

Taulukko 1 osoittanee, että - ottaen huomioon kuntien suhteellisen pienen lukumäärän - lukiotutkimuksen piiriin valittujen koulujen paikkakunnat edustavat kohtalaisen hyvin, osittain laidasta laitaan, Suomen kuntien välillä nykyään todettuja tavallisimpia eroavuuksia ja että harkintanäyte ainakin tässä suhteessa lienee välttänyt ilmeisiä yksipuolisuuksia.

Kouluja valittaessa (mikä käytännössä tuli vaikuttamaan myös paikkakuntien valintaan, koska pienillä paikkakunnilla on vain $1-2$ oppikoulua) pyrittiin saamaan mukaan sekä valtion ja kunnan että yksityisiä oppikouluja, sekä vanhoja että nuoria, sekä suuria että pieniä kouluja, ja muuten etsimään kouluja, joiden opetusohjelma tai muut piirteet eivät jyrkästi poikkeaisi 1960-luvulla »tavallisesta». (Viimeksimainittu vaatimus karsi pois myös pelkät poika- tai tyttökoulut, koska niiden osuus Suomen oppikouluista on vain n. 10 \%.) Kustakin kaupungista valittiin

1) luvut Suomen Tilastollisen Vuosikirjan 1965 taulusta 24

from Statistical Yearbook of Finland, 1965, Table 14

2) Palmgren 1964

3) Riihinen 1965

4) Tilastollisen Päätoimiston v. 1960 väestönlaskennan julkaisemattomia tietoja Unpublished data of the 1960 census from the Central Statistical Office of Finland 
Taulukko 2. Tutkimuskoulujen oppilaiden huoltajien ammattijakauma ja kaikkien suomenkielisten oppikoulujen oppilaiden huoltajien vastaava jakauma lukuvuonna 1964/65 (Oppikoulut 1964/65, taulu 24)

Table 2. Comparison of the occupational distribution of the primary guardians of students in the project schools and that of students in all Finnish language secondary schools in 1964/65

\begin{tabular}{lll}
\hline Huoltajan ammatti & Tutkimuskoulujen & Kaikki suomen- \\
$\begin{array}{l}\text { Occupation of } \\
\text { primary guardian }\end{array}$ & oppilaat $64 / 65$ & kieliset oppikou- \\
& Students of Project & lut $64 / 65$ \\
& Schools & All Finnish \\
& & language \\
\hline
\end{tabular}

1. Maa- ja metsätalous -

21.5

Agriculture and forestry

Farmers ............

b. Muita yrittäjiä ja toimihenkilöitä Other independent entrepreneurs and functionaries

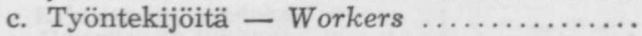

2. Teollisuus, käsityö ja rakennustoiminta Industry, handicrafts and construction

a. Yrittäjiä ja toimihenkilöitä Employers and functionaries

b. Itsenäisiä käsityöläisiä -

Independent handicraft workers

c. Työntekijöitä - Workers ................

3. Kauppa - Commerce

a. Yrittäjiä ja toimihenkilöitä -

Employers and functionaries

b. Työntekijöitä - Workers

4. Liikenne - Transport and communication

a. Yrittäjiä ja toimihenkilöitä -

Employers and functionaries

5. Palvelukset yhteiskunnalle ja elinkeinoelämälle (julkinen toiminta, vapaat ammatit) Public office and professional workers

a. Valtion, kirkon ja kunnan virk. State, church and communal employers.

b. Opettajia (korkeakoulut, koulut, opistot) - Teachers (universities, schools, others)

c. Lääkintähenkilöstöä - Health services

d. Kirjailijoita ja taiteilijoita Writers and artists

e. Yhdist. ja järj. virkailijoita Employers of voluntary associations

f. Työntekijöitä ja palveluskuntaa Manual and service workers

16.1

4.0

33.0

13.9

17.1

12.3

10.9

6. Henkilölliset palvelukset -

Personal services

a. Yrittäjiä ja toimihenkilöitä -

Employers and functionaries
25.9

21.5

3.0

1.4

31.2

12.6

12.2

10.5

10.5

5.4
Domestic and other personal service workers 
7. Tuntematon elinkeino - Occupation unknown

a. Yrittäjiä ja toimihenkilöitä -

$\begin{array}{ll}0.8 & 0.8\end{array}$

Employers and functionaries

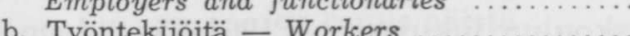

Tyontekijöitä - Workers ...............

c. Tuntematon ammattiasema -

Occupation unknown

8. Ilman ammattia - No occupation

kaksi koulua, maalaiskunnissa oli vain yksi koulu kussakin. Näin saatiin kaikkiaan 13 tutkimuskoulua, joista kahdella ei ollut omaa lukiota.

Kun paikkakuntien ja koulujen valinnassa pääpaino oli pantu mahdollisuuteen vertailla erilaisia ympäristöjä, kohoaa esille kysymys, missä määrin näin saatu yhdistelmä kouluja voi hahmotella myös yleiskuvaa, jolla olisi yhteyttä koko maan koululaisten piirteisiin. Erään mahdollisuuden tämän tarkasteluun tarjoaa taulukko 2 , jossa on esitetty yhdistelmä näiden 13 tutkimuskoulun Tilastolliselle päätoimistolle lukuvuonna 1964/65 antamista tiedoista kaikkien oppilaittensa ensisijaisten huoltajien ammateista sekä verrattu tätä prosenttijakaumaa virallisen oppikoulutilaston (Oppikoulut 1964/65, taulu 24) tietoon kaikkien suomenkielisten oppikoulujen oppilaiden ensisijaisten huoltajien ammattijakaumasta.

Taulukosta näkyy, että vaikka lukiotutkimuksen 13 koulua lukuvuonna 1964/65 edustivat vain $2.5 \%$ suomenkielisten oppikoulujen lukumäärästä (524) ja niiden yhteinen oppilasmäärä $3.4 \%$ kaikista suomenkielisten koulujen oppilaista (1964/65 242 784), tutkimuskoulujen oppilaiden kotien ammatillinen tausta vastasi sangen läheisesti koko maan tilannetta. Huomattavin aliedustus on todettavissa maa- ja metsätalouden, huomattavin yliedustus taas toisaalta teollisuuden, toisaalta julkisen toiminnan ja vapaiden ammattien kohdalla. Tämä poikkeama johtuu luultavasti olennaisimmin siitä, että lukiotutkimuksen kouluista vain n. $38 \%$ sijaitsi maalaiskunnissa, kun vastaava osuus kaikista suomenkielisistä oppikouluista oli $51 \%$. Mikäli taas lukiotutkimuksen päätarkoituksen vuoksi vain yliopistoon johtavat koulut otetaan huomioon, oli lukiotutkimuksessa näistä maalaiskunnissa sijaitsevien osuus $27 \%$, kun se koko maassa oli $37 \%$.

Maatalousväestön jatkuvan vähenemisen ja maalaiskuntien kaupunkimaistumisen vuoksi on mainitunlainen edustavuusero tulevaisuutta koskevien johtopäätösten kannalta kuitenkin vähemmän haitallinen kuin päinvastainen eroavuus olisi. Eri ammattiryhmien osuudet seurailevat kuitenkin suuruusluokiltaan niin hyvin koko maan osuuksia, että tutkimuskoulujen keskikoulun viimeisen luokan oppilaista yhteisesti muodostuvan kuvan voidaan, e.m. varaukset huomioon ottaen, tuskin odottaa vievän pahasti harhaan laajemmallekin yleistettynä. 


\section{Millaisia ovat 1960-luvulla keskikoulua päättävät oppilaat?}

Edelläselostettujen 13 tutkimuskoulun lukuvuonna 1964/65 viidennellä luokalla olleet oppilaat muodostivat siis suomalaisen lukiotutkimuksen lähtökohdan. Lukuunottamatta muutamaa luokilla vain pari viikkoa tai kuukauden ollutta henkilöä he kaikki vastasivat ensimmäisiin kyselylomakkeihin ja olivat siis lukiotutkimuksen alkuperäisiä tutkimushenkilöitä, luvultaan 1435 eli $3.9 \%$ kaikista suomenkielisten oppikoulujen keskikouluasteen viimeisen luokan oppilaista lukuvuonna 1964/65 (luvultaan 36 416). Taulukossa 3 nämä tutkimushenkilöt sekä heidän koulunsa ja luokkansa on esitelty.

Alkuperäiset 1435 tutkimushenkilöä olivat kouluissa 38 eri rinnakkaisosastolla. Luokkaryhmien keskimääräinen suuruus oli 37.2 oppilasta ja niiden mediaani 38.5 oppilaan suuruinen, mitkä molemmat luvut huomattavasti ylittävät virallisen oppikoulutilaston ilmoittaman luokkien koon keskimäärän 34.2 oppilasta suomenkielisissä oppikouluissa. Koko maan keskiarvoa ilmeisesti laskevat sekä monien pienten maalaiskoulujen pienet luokat että lukiossa keskikoulua pienemmät luokkaryhmät. Näyttää kuitenkin todennäköiseltä, että nimenomaan juuri keskikoulun viimeiset luokat ovat 1960-luvulla olleet tavallista suuremmat, ylittäähän niiden kokonaisoppilasmäärä usein neljä vuotta aikaisemmin oppikouluun otettujen määrän välillä tapahtuneista keskeytyksistä huolimatta (Sysiharju 1966 a, taulu 3). Tämä taas johtunee luokallejäämisistä keskikoulun aikana ja erityisen voimakkaaksi kasvaneesta tahallisesta jäämisestä juuri keskikoulun viimeiselle luokalle, johon virallinen oppikoulutilastokin on kiinnittänyt huomiota (Oppikoulut 1963/64, 6). Samaan luokallejäämisilmiöön palataan myös tässä kirjoituksessa myöhemmin. Joka tapauksessa on todettava, että $3 / 4$ lukiotutkimuksen alkuperäisistä tutkimushenkilöistä oli päättämässä keskikouluopintojaan ja tekemässä päätöksiään jatko-opinnoista opiskelutilanteessa, jossa luokkaryhmän suuruus vaihteli 36-46 oppilaaseen. Näin suuriin opetusryhmiin liittyy ainakin tavanomaisia opetusmenetelmiä käytettäessä yksityisen oppilaan kannalta monia haittoja, ennenkaikkea opettajan yksilöllisen huomion puuttuminen.

T y t tö j e n suhteellisen korkea osuus, $58.3 \%$, alkuperäisistä tutkimushenkilöistä on selvästi korkeampi kuin vastaava osuus samojen koulujen koko oppilasmäärästä $56.5 \%$, joka on tarkalleen sama kuin kaikkien suomenkielisten oppikoulujen tyttöprosentti lukuvuonna 1963/64 (Oppikoulut 1963/64, taulu 4). Näyttää siis siltä, että tässäkin on kyseessä pikemmin keskikoulun viimeisille luokille yleensä ominainen piirre kuin tutkimuskoulujen satunnainen poikkeama. Olen jo aikaisemmin (Sysiharju 1966 b) kiinnittänyt huomiota siihen, että tytöt ovat jo kauan olleet enemmistönä oppikouluun otetuista (1960 $55.8 \%$ ), mutta että tämä enemmistö näyttää keskikoulun aikana vain kasvavan, luultavasti lähinnä siksi, että pojat 
T a u lukko 3. Tutkimuskoulujen oppilasmäärät ja tyttöjen osuus niistä, koulujen viidennet luokat, niiden oppilasmäärä ja tyttöjen osuus näistä

Table 3. Student frequencies and proportion of girls in the Project Schools; class sections, student frequencies and proportion of girls in last grade of Junior Secondary

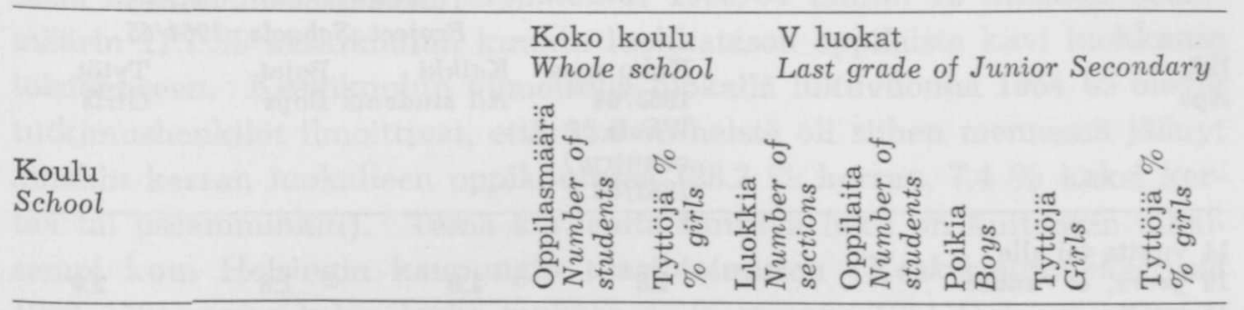

Etelä-Suomen kaupungit

South Finland - cities

Kaupunki A-koulu

City A-school 1 ..........

Kaupunki A-koulu 2 ........

City A-school $2 \ldots \ldots$....

$\begin{array}{lllllll}692 & 57 & 2 & 75 & 33 & 42 & 56.0\end{array}$

Kaupunki B-koulu $1 \ldots \ldots$. . .

$\begin{array}{llll}\text { City } & B-s c h o o l & 1 & \ldots \ldots \\ \text { Kaupunki } & \text { B-koulu } & 2\end{array}$

$\begin{array}{lllllll}891 & 53 & 5 & 188 & 81 & 107 & 56.9\end{array}$

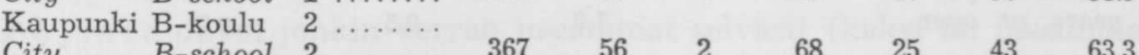

Etelä-Suomen maalaiskunnat

South Finland - rural communes

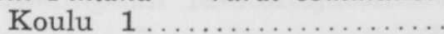

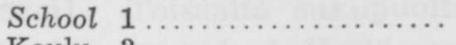

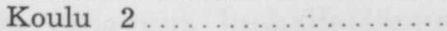

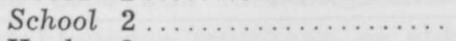

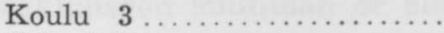

School $3 \ldots \ldots \ldots \ldots \ldots \ldots \ldots$.

$\begin{array}{lllllll}653 & 55 & 3 & 138 & 58 & 80 & 58.0\end{array}$

$\begin{array}{lllllll}544 & 56 & 2 & 85 & 33 & 52 & 61.1\end{array}$

$\begin{array}{lllllll}190 & 59 & 1 & 25 & 10 & 15 & 60.0\end{array}$

Pohjois- \& Itä-Suomen kaupungit

North \& East Finland - cities

Kaupunki A-koulu 1

City A-school $1 \ldots \ldots .$.

Kaupunki A-koulu 2 ........

City A-school 2 .......

Kaupunki B-koulu 1 .......

$\begin{array}{llll}\text { City } & \text { B-school } & 1 & \ldots \ldots \\ \text { Kaupunki } & \text { B-koulu } & 2\end{array}$

City B-school 2 ..........

$\begin{array}{lllllll}1004 & 54 & 5 & 176 & 80 & 96 & 54.5\end{array}$

$\begin{array}{llllllll}841 & 57 & 4 & 168 & 73 & 95 & 56.6\end{array}$

$\begin{array}{lllllll}680 & 57 & 4 & 152 & 63 & 89 & 58.6\end{array}$

$\begin{array}{lllllll}692 & 58 & 2 & 84 & 37 & 47 & 56.0\end{array}$

Itä-Suomen maalaiskunnat

East Finland - rural communes

Koulu 1 . .

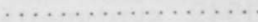

School 1 ..................

School 2

$\begin{array}{rrrrrrr}467 & 61 & 2 & 68 & 23 & 45 & 66.3 \\ 357 & 56 & 2 & 45 & 17 & 28 & 62.3 \\ 8412 & 56.5 & 38 & 1435 & 600 & 835 & 58.3\end{array}$

useammin kuin tytöt keskeyttävät opintonsa. Joka tapauksessa tämä tyttövaltaisuus on syytä ottaa tosiasiana huomioon pohdittaessa nykyistä keskikoulua päättävien tilannetta. - Taulukko 3 viittaa myös siihen, että maalaiskuntien kouluissa tyttöenemmistö oli kaupunkikouluja suurempi, mikä jälleen vastaa hyvin myös koko maan lukuja. Niiden mukaan tyttöjen 
Taulukko 4. Tutkimuskoulujen ja koko maan viidesluokkalaisten ikäjakaumat

Table 4. Age distribution of students in the last grade of Junior Secondary in the Project Schools and in the whole country

\begin{tabular}{|c|c|c|c|c|}
\hline \multirow[b]{2}{*}{$\begin{array}{l}\text { Ikä } \\
\text { Age }\end{array}$} & \multirow[b]{2}{*}{$\begin{array}{l}\text { Koko maa } \\
1963 / 64 \\
\text { Whole } \\
\text { country } 1 \text { ) } \\
1963 / 64\end{array}$} & \multicolumn{2}{|c|}{$\begin{array}{l}\text { Tutkimuskoulut } \\
\text { Project Schools }\end{array}$} & \multirow{2}{*}{$\begin{array}{c}1964 / 65 \\
1964 / 65 \\
\text { Tytöt } \\
\text { Girls }\end{array}$} \\
\hline & & $\begin{array}{l}\text { Kaikki } \\
\text { All students }\end{array}$ & $\begin{array}{l}\text { Pojat } \\
\text { Boys }\end{array}$ & \\
\hline $\begin{array}{l}14 \text { vuotta tai alle } \\
14 \text { years, or under }\end{array}$ & 1.8 & 1.9 & 1.8 & 2.0 \\
\hline $\begin{array}{l}15 \text { vuotta } \\
15 \text { years } \\
16 \text { vuotta }\end{array}$ & 35.2 & 43.8 & 43.3 & 44.1 \\
\hline $\begin{array}{l}16 \text { years } \\
17 \text { vuotta }\end{array}$ & 35.6 & 33.9 & 31.3 & 35.7 \\
\hline $\begin{array}{l}17 \text { years } \\
18 \text { vuotta }\end{array}$ & 20.1 & 16.0 & 18.0 & 14.6 \\
\hline $\begin{array}{l}18 \text { years } \\
19 \text { vuotta tai yli }\end{array}$ & 6.1 & 3.9 & 4.8 & 3.2 \\
\hline 19 years, or over & 1.2 & 0.5 & 0.7 & 0.4 \\
\hline $\begin{array}{l}\text { Yhteensä - Total \% } \\
\text { Lukumäärä - Number }\end{array}$ & $\begin{array}{r}100.0 \\
38929\end{array}$ & $\begin{array}{r}100.0 \\
1435\end{array}$ & $\begin{array}{r}100.0 \\
600\end{array}$ & $\begin{array}{r}100.0 \\
835\end{array}$ \\
\hline $\begin{array}{l}\text { 1) Laskettu Oppikoulut } 1963 / 6 \\
\text { From Oppikoulut } 1963 / 64\end{array}$ & $\begin{array}{l}\text { usta } 22 . \\
\text { le } 22 .\end{array}$ & & & \\
\hline
\end{tabular}

osuus keskikouluasteen oppilaista oli 1963/64 kaupunkikouluissa $55.6 \%$, mutta maalaiskuntien kouluissa $58.5 \%$ (laskettuna Oppikoulut 1963/64 taulusta 26).

Tutkimushenkilöryhmän ikää keskikoulun viimeisellä luokalla 1964/65 esittävä taulukko 4 osoittaa ehkä yllättävän suurelta tuntuvan osan $(20.4 \%)$ heistä olevan vähintäin kaksi vuotta yli »normaali-iän», mutta että vastaava osuus koko maassa $(27.4 \%$ ) on vieläkin suurempi. (Tässä lienee kuitenkin muistettava iltakoululaisten osuus.) Tutkitussa ryhmässä oli selvästi enemmän täysin »normaali-ikäisiä» (1949 syntyneitä) kuin koko maan keskikouluaan päättävissä, mutta sittenkään tämä osuus ei yltänyt edes puoleen ryhmästä. Näyttää siltä, että nykyisen oppikoulun tällä luokkatasolla yhden vuoden "myöhästyminen» on jopa tavallisempaa kuin normaali-ikäisyys. Samasta oppikoululaisten ikää koskevasta virallisen tilaston taulusta (Oppikoulut 1963/64, taulu 22) voidaan laskea, että vaikka lukuvuonna 1963/64 noin $35 \%$ vuoden 1948 ikäluokasta (100 487) oli oppikoulussa, vain noin $14 \%$ tästä ikäluokasta oli sille »normaalilla» keskikoulun viimeisellä luokalla.

Melkoinen osa tästä myöhästymisestä on tapahtunut jo oppikouluun siirryttäessä. $31.6 \%$ tutkimushenkilöistä ilmoitti siirtyneensä oppikouluun 
vasta kansakoulun $\mathrm{V}$ luokalta tai myöhemmin, samoin voidaan mainitusta virallisen oppikoulutilaston ikätaulusta laskea, että noin $40 \%$ jo oppikoulun ensimmäisen (tai sitä vastaavan) luokkatason oppilaista oli "yliikäisiä».

Todennäköisesti vielä enemmän myöhästymistä aiheutuu luokallejäämisestä keskikoulun aikana. Oppikoulut 1963/64 taulun 13 mukaan keskimäärin $11.7 \%$ keskikoulun kunkin luokkatason oppilaista kävi luokkansa toistamiseen. Keskikoulun viimeisellä luokalla lukuvuonna 1964/65 olevat tutkimushenkilöt ilmoittivat, että $35.6 \%$ heistä oli siihen mennessä jäänyt ainakin kerran luokalleen oppikoulussa (28.2 \% kerran, $7.4 \%$ kaksi kertaa tai useamminkin). Tämä korkealta tuntuva luku on kuitenkin alhaisempi kuin Helsingin kaupungin tilastotoimiston (Keskikoulumenestystä 1960, 112) saama tulos, jonka mukaan $47 \%$ vuonna 1951 Helsingissä oppikouluun otetuista 2829 oppilaasta oli ennen lukuvuotta $1957 / 58$ jäänyt ainakin kerran luokalleen (tässä ovat myös ennen keskikoulun päättymistä eronneet mukana) tai Kiviluodon 1956 seuraantotutkimuksessaan ilmoittama tieto, että Tampereella 1950/52 oppikouluun siirtyneistä 367 oppilaasta $44 \%$ kävi jonkun luokan kahteen kertaan keskikoulussa.

$\mathrm{P}$ oj is t a olivat jonkin verran useammat selvästi (kaksi tai useamman vuoden) yli-ikäisiä kuin tytöistä, mikä ilmeisesti liittyy poikien selvästi runsaampaan luokallejäämiseen (41.2\% pojista, $31.6 \%$ tytöistä ainakin kerran). Toisaalta sukupuolten ikäerot eivät näytä aivan niin jyrkiltä kuin eroavuus luokallejäämisessä edellyttäisi. Niitä tasoittaa ilmeisesti vastakkaiseen suuntaan se ehkä yllättävältä tuntuva tosiasia, että nimenomaan tytöt ovat useammin $(34.6 \%)$ kuin pojat $(27.4 \%)$ siirtyneet "normaalia» kansakoulun IV luokkaa myöhemmin oppikouluun.

Keskikoulua päättävien oppilaiden ikäasteikon ulottuminen 14 vuodesta 19 vuoteen ja ylikin ei koskenut ainoastaan koko tutkimusjoukkoa vaan myös erillisiä kouluja. Neljässä niistä esiintyi koko ikäalue eivätkä ikäerot missään jääneet $2-3$ vuotta pienemmiksi. Tämä puolestaan asettaa jo sinänsä eri oppilaat sekä yhteiskunnan että omissa silmissään erilaiseen tilanteeseen ajatellen niitä valintoja, joita heidän olisi juuri keskikoulun päättyessä tulevaisuuttaan varten suoritettava.

Samaan aikaan keskikouluaan päättämässä olevilla oppilailla ei ole takanaan vain ajallisesti erilaisia koulumenneisyyksiä. Nyky-yhteiskunnassa varttuvina nuorina heistä ovat monet myös jo kokeneet sekä useita kotipaikkakuntia että useita kouluja. $37.5 \%$ (maalaiskuntien kouluissa 16-37\%, kaupunkien kouluissa $30-54 \%$ ) tutkimushenkilöistä ilmoitti vaihtaneensa kotikuntaa ainakin kerran elinaikanaan, $29.5 \%$ heistä (maalaiskuntien kouluissa 8-18\%, kaupunkikouluissa 19-51\%) oli käynyt useampaa kuin yhtä kansakoulua ja $12.7 \%$ oli tähän mennessä vaihtanut oppikoulua ainakin kerran (maalaiskuntien kouluissa $0-7 \%$, kaupunkikouluissa $3-25 \%$.). 
Myös nykyhetkellä vaati oppikoulun käyminen monilta melkoista liikkuvuutta. Tutkimushenkilöistä $21.8 \%$ asui toisessa kunnassa kuin oppikoulunsa (Oppikoulut 1963/64 taulun 10 mukaan osuus olisi koko maan oppikoululaisista $24 \%$ ). Ellei oteta huomioon Helsingin kouluja, vaihteli kaupunkikouluissakin maalaiskunnissa asuvien oppilaiden osuus 20.8-32.1 \%. Maalaiskuntien kouluista oli nimenomaan Etelä-Suomen kouluissa 42.8-44.6 \% keskikoulun viimeisen luokan oppilaista toisesta kunnasta.

Kodin etäisyys pakotti $6.4 \%$ kaikista tutkimushenkilöistä asumaan kouluasunnossa, mutta suhde kohosi parissa maalaiskuntakoulussa 20.0_ $29.4 \%$ asti. Lisäksi $8.9 \%$ näistä keskikoulun viimeisen luokan oppilaista ilmoitti käyttävänsä koulumatkoihin päivittäin kaksi tuntia tai sitä enemmän. Kahdessa kunnallisessa keskikoulussa, joissa on ilmainen koulukuljetus, nousivat nämä osuudet $24.4-32.0 \%$, mutta on huomattava, että kaikista 13 tutkimuskoulusta vain neljässä (kaikki kaupungeissa) näin pitkämatkaisten oppilaiden osuus oli alle kymmenen prosentin.

On mahdollista tarkastella myös 1960-luvulla keskikoulunsa päättävien nuorten kotitaustaa lukiotutkimuksen lähtökohtana olleista lähes 1500 oppilaasta saatujen tietojen valossa. $88.8 \%$ tutkimushenkilöistä ilmoitti ensisijaiseksi huoltajakseen isän (90.2 \% pojista, $87.9 \%$ tytöistä), $8.7 \%$ äidin (6.8 \% pojista, $10.1 \%$ tytöistä) ja $2.2 \%$ jonkun muun $(2.5 \%$ pojista, $1.9 \%$ tytöistä). Sukupuolten välinen ero näyttää ehkä odottamattomalta, kun ei liene oletettavissa, että »epätavallisia» perhetilanteita sinänsä osuisi epätasaisesti eri sukupuolta olevien lasten kohdalle. Sen sijaan lienee mahdollista ja eräiden havaintojen ja tutkimustulosten mukaistakin, että äidin joutuessa yksin huoltamaan lapsia juuri poikien sopeutumisessa - kouluopintojen jatkamista myöten - voi olla suurempia vaikeuksia.

Taulukko 5 antaa tietoja edellämainittujen ensisijaisten huoltajien jakautumisesta sekä erilaisiin ammattiryhmiin että saamansa yleiskoulutuksen mukaan. Tässä käytetty ammattiryhmitys noudattaa Wariksen $(1948,1952)$ alkujaan käytäntöön ottamaa yhteiskuntaryhmien nelijakoa: työväestö, maanviljelijät, keskikerros ja ylin kerros (myös Nieminen 1958 ja Rauhala 1964), mutta lisäksi on käytetty alaryhmityksiä, jotta voitaisiin saada tarkemmin selville eri ammattiryhmien keskuudessa mahdollisesti vallitsevia eroavuuksia suhtautumisessa koulutukseen.

Tämä taulukko osoittaa, samoin kuin jo aikaisemmin taulukossa 1 esitetyt tiedotkin kaikkien oppikoulujen oppilaista, että keskikouluasteen oppilaiden kodit edustavat kaikkia yhteiskuntaryhmiä. Tilanne osoittautui myös samaksi kunkin kolmentoista tutkimuskoulun kohdalla aina maanviljelijäkoteja myöten, jotka olivat kaikissa kaupunkikouluissakin edustettuina vain molempia helsinkiläiskouluja lukuunottamatta. Lähes puolet näistä $(45.9 \%)$ keskikouluaan päättävistä nuorista oli maanviljelijä- tai työväestökodeista eikä tämä osuus missään koulussa laskenut alle neljänneksen. Toisaalta oli useimmissa tutkimuskouluissa alle $5 \%$ oppilaiden huoltajien 
Ta u lukko 5. Tutkimuskoulujen viidesluokkalaisten huoltajien sosiaaliset kerrostumat ja yleiskoulutus

Table 5. Distribution of the primary guardians of students in the last grade of Junior Secondary in the Project Schools, according to social class and education

\begin{tabular}{|c|c|c|c|}
\hline $\begin{array}{l}\text { Huoltajan sosiaalinen kerrostuma } \\
\text { Social class of primary quardian }\end{array}$ & $\begin{array}{l}\text { Kaikki } \\
\text { All students }\end{array}$ & $\begin{array}{l}\text { Pojat } \\
\text { s Boys }\end{array}$ & $\begin{array}{l}\text { Tytöt } \\
\text { Girls }\end{array}$ \\
\hline $\begin{array}{l}\text { Työväestö: ammattitaidoton }- \\
\text { Workers: unskilled } \ldots \ldots \ldots \ldots \ldots \ldots \ldots \ldots \ldots \ldots \\
\text { Työväestö: ammattitaitoinen - }\end{array}$ & 7.6 & 6.2 & 8.6 \\
\hline $\begin{array}{l}\text { Workers: skilled } \\
\text { Työväestö yhteensä }-\end{array}$ & 25.0 & 23.8 & 25.9 \\
\hline Workers: total ............... & 32.6 & 30.0 & 34.5 \\
\hline $\begin{array}{l}\text { Maanviljelijät: alle } 5 \text { ha viljeltyä maata }- \\
\text { Farmers: under } 5 \text { hectares arable land } \ldots \ldots \\
\text { Maanvilieliiät: } 5 \text { - } 15 \text { ha vilieltyä maata }-\end{array}$ & 1.6 & 1.5 & 1.7 \\
\hline $\begin{array}{l}\text { Farmers: } 5 \text {-15 hectares arable land } \ldots \ldots \ldots \ldots \\
\text { Maanviljelijät: yli } 15 \text { ha viljeltyä maata }-\end{array}$ & 5.6 & 5.5 & 5.7 \\
\hline $\begin{array}{l}\text { Farmers: over } 15 \text { hectares arable land ......... } \\
\text { Maanviljelijät yhteensä - }\end{array}$ & 6.1 & 5.3 & 6.6 \\
\hline 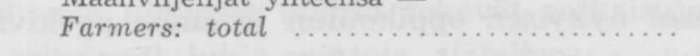 & 13.3 & 12.3 & 14.0 \\
\hline $\begin{array}{l}\text { Keskikerros: toimihenkilöt - } \\
\text { Middle class: functionaries } \\
\text { Keskikerros: itsenäiset yrittäjät - }\end{array}$ & 33.6 & 36.5 & 31.5 \\
\hline $\begin{array}{l}\text { Middle class: independent entrepreneurs } \\
\text { Keskikerros: opettajat (ei akat. loppututkintoa) }\end{array}$ & 8.8 & 7.7 & 9.7 \\
\hline $\begin{array}{l}\text { Middle class: teachers (no university degree) } \\
\text { Keskikerros yhteensä - }\end{array}$ & 2.6 & 2.8 & 2.4 \\
\hline Middle class: total ...................... & 45.0 & 47.0 & 43.6 \\
\hline $\begin{array}{l}\text { Ylin kerros (vastuullinen johto, akat. lopputut- } \\
\text { kinto) - Upper class: professional, managerial } \\
\text { and administrative workers ................... }\end{array}$ & 7.0 & 8.8 & 5.7 \\
\hline Ei tietoa - No information .... & 2.0 & 1.8 & 2.2 \\
\hline $\begin{array}{l}\text { Yhteensä Total } \% \\
\text { Lukumäärä }- \text { Number } \ldots \ldots \ldots \ldots \ldots \ldots \ldots \ldots \ldots \ldots \ldots \ldots \ldots \ldots\end{array}$ & $\begin{array}{r}100.0 \\
1435\end{array}$ & $\begin{array}{r}100.0 \\
600\end{array}$ & $\begin{array}{r}100.0 \\
835\end{array}$ \\
\hline \multicolumn{4}{|l|}{$\begin{array}{l}\text { Huoltajien yleiskoulutus } \\
\text { Education of primary guardians }\end{array}$} \\
\hline $\begin{array}{l}\text { Kansakoulu - Elementary school ............. } \\
\text { Keskikoulu - Junior Secondary .......... } \\
\text { Lukio, yo-tutkinto - Senior Secondary, Mat- }\end{array}$ & $\begin{array}{l}71.7 \\
15.7\end{array}$ & $\begin{array}{l}65.0 \\
18.0\end{array}$ & $\begin{array}{l}75.3 \\
14.1\end{array}$ \\
\hline $\begin{array}{l}\text { riculation Exam. } \\
\text { Akateeminen loppututkinto - University degree }\end{array}$ & $\begin{array}{l}5.4 \\
6.8\end{array}$ & $\begin{array}{l}6.8 \\
8.5\end{array}$ & $\begin{array}{l}4.4 \\
5.5\end{array}$ \\
\hline Ei tietoa - No information & 1.0 & 1.3 & 0.7 \\
\hline 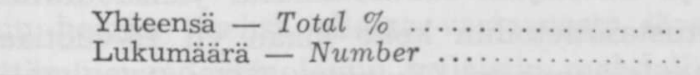 & $\begin{array}{r}100.0 \\
1435\end{array}$ & $\begin{array}{r}100.0 \\
600\end{array}$ & $\begin{array}{r}100.0 \\
835\end{array}$ \\
\hline
\end{tabular}

ammateista "ylimpään kerrokseen" ryhmitettyjä (varsinaiset akateemiset loppututkinnot, vastuunalaiset johtavat toimet julkisella sektorilla sekä teollisuuden ja kaupan piirissä) ja vain kolmessa kaupunkikoulussa tämä suhdeluku ylitti $10 \%$ keskikoulun viimeisen luokan oppilaista. Vaikka eri yhteiskuntaryhmien osuudet eivät vielä vastaakaan niiden väestöosuuksia (Rauhalan 1964 mukaan vuoden 1960 väestönlaskennassa ammatissa- 
toimivasta väestöstä $51 \%$ oli luettavissa työväestöön, $16 \%$ maatalousväkeen, $30 \%$ keskikerrokseen sekä $3 \%$ ylimpään kerrokseen), voidaan kuitenkin todeta, että keskikoulun viimeisellä luokalla hyvin monenlaisista kotiympäristöistä tulevat nuoret opiskelivat tovereina yhdessä ja joutuivat yhdessä samojen tulevaisuudenratkaisujen eteen.

Poikien ja tyttöjen kotitaustassa näyttää olleen eräitä pieniä, mutta näin suuren lukumäärän puitteissa merkitseviksi ja mielenkiintoisiksi nousevia eroavuuksia. Poikien huoltajat olivat suhteellisesti useammin ylimpään tai keskikerrokseen luettavissa ammateissa, tyttöjen huoltajat taas maanviljelijöihin tai työväestöön kuuluvia. Sen, ettei tämä eroavuus ole aiheutunut pelkästään satunnaisuuksista ammattien ryhmittelyssä, osoittaa samansuuntaisen eroavuuden näkyminen vielä voimakkaampana taulukon 5 b)-osassa, huoltajien jakautumisessa saamansa yleiskoulutuksen mukaan. Tyttöjen huoltajilla oli takanaan selvästi useammin vain kansakoulu, poikien huoltajista taas useammat olivat käyneet keskikoulua ja lukiota tai suorittaneet akateemisen loppututkinnon. Olen aikaisemmin (Sysiharju 1966 b), pohtiessani nykyisen oppikoulun jo sinne pyrkivistä alkavaa tyttöenemmistöä, esittänyt tämän sukupuolten erilaista kotitaustaa koskevan havainnon selitysmahdollisuudeksi seuraavien olettamusten yhdistelmän: 1) pojat sopeutuvat ja viihtyvät koulussa huonommin kuin tytöt (tämä on yleismaailmallinen havainto, mutta suomalainen poika ja suomalainen koulu saattavat olla erityisen huonosti yhteensoveltuvia); 2) suomalaisten kotien kasvatusasenne lienee koulutusasioissa usein luonnehdittava lähinnä »sallivaksi», »antaa lapsen tehdä kuten itse haluaa»-tyyliseksi. Näin kodit sallisivat sekä kouluhaluttomien poikien olla pyrkimättä tai keskeyttää oppikoulussa että sitä haluavien tyttöjen pyrkiä kouluun tai jatkaa siinä; 3) tämä »sallivuus» olisi voimakkain niissä kodeissa, joissa omakohtainen koulutuskokemus on vähäisin - kodeissa, joissa huoltajalla itsellään on runsaammin koulutusta, pyrittäisiin suuremmassa määrin kouluttamaan myös siihen vähemmän halukkaita poikia ainakin keskikoulun läpi. Sekä itse ilmiötä että sen selitystä on syytä edelleen tutkia, mutta joka tapauksessa on, vertailtaessa sukupuolten ratkaisuja keskikoulusta eteenpäin lähdettäessä, otettava huomioon myös kotitaustan erilaisuuden vaikutukset.

Taulukon 5 b)-osan tietoja huoltajien saavuttamasta yleiskoulutustasosta voidaan verrata koulutustasotietoihin koko maan yli 15-vuotiaasta väestöstä vuoden 1960 väestönlaskennassa (Suomen Tilastollinen Vuosikirja 1965, taulu 19), joiden mukaan pelkän keskikoulututkinnon suorittaneiden osuus oli $7.6 \%$ (kaupungeissa $12.2 \%$ ), ylioppilastutkinnon ilman akateemista loppututkintoa suorittaneiden $2.5 \%$ (kaupungeissa 4.3 $\%$ ) sekä akateemisen loppututkinnon suorittaneiden osuus $1.7 \%$ (kaupungeissa $3.2 \%)$. Mikäli suoraa vertailua voi tehdä, olisivat siis keskikouluaan päättävien nuorten huoltajissa keskikoulututkinnon ja pelkän ylioppilastutkinnon suorittaneet noin kaksinkertaisesti ja akateemisen 
loppututkinnon suorittaneet noin kolme-neljäkertaisesti yliedustettuja eli - yleisten odotusten mukaisesti - huoltajan itsensä saama pitempi yleiskoulutus lisää todennäköisyyttä, että lapsi siirtyy oppikouluun ja myös käy keskikoulunsa loppuun.

Tästä huolimatta tuo taulukon $5 \mathrm{~b}$ )-osa kuitenkin ennenkaikkea voimakkaasti esille sen tosiasian, että suurin osa, ainakin lähes kolme neljännestä nykyisistä keskikouluaan päättävistä edustaa tässä suhteessa "ensimmäistä sukupolvea», t.s. heidän vanhempansa eivät ole tätä koulua käyneet. Samoin, kun näiden oppilaiden olisi tehtävä ratkaisu opintojen jatkamisesta nimenomaan lukiossa, on heistä vain runsaasti joka kymmenennellä oppilaalla lukiosta omakohtaista kokemusta saanut huoltaja.

Edellä esitettyjä tietoja keskikouluaan nykyisin päättävästä nuorisojoukosta voidaan tarkastella ainakin kahdelta kannalta: ensiksikin nykyisen keskikoulun toimintakentän ja toimintatavan kuvauksena, josta voi olla hyötyä peruskoulu-uudistuksessa huomioonotettavia seikkoja harkittaessa, sekä toiseksi tietona niistä edellytyksistä ja tilanteista, joiden vallitessa nykyiset nuoret tekevät ratkaisujaan nuorisoasteen koulutusta ja erityisesti lukio-opintoja ajatellen.

Ensimmäisestä näkökulmasta ajatellen lienee syytä korostaa nykyisen keskikoulunuorison paikallista liikkuvuutta sekä muutenkin kaikinpuolista monipuolisuutta ja keskinäistä erilaisuutta, joka tekee yleistykset ja ryhmittelyt vaikeiksi sekä tutkimuksessa että käytännön koulujärjestelyissä. Suomalainen oppikoulu on, toisin kuin useissa keski-eurooppalaisissa maissa, jo nyt pitkälti kehittynyt yleiseksi peruskouluksi kaikille. Toisaalta kiinnittyy huomio tällä hetkellä vallitsevaan laajaan opintojen myöhästymiseen ja myös keskeytymiseen. Koulu-uudistuksessa olisi ehkä kiinnitettävä erityistä huomiota siihen oppilasryhmään, usein varsinkin murrosikäisiin poikiin, jota nämä nykyisessä oppikoulussa edustavat ja pyrittävä tutkimaan sekä heidän yksilöllisiä piirteitään että koulu- ja kotiolosuhteitaan.

Tarkasteltaessa tässä tehtyjä havaintoja toisesta, oppilaiden edessä olevia valintoja koskevasta näkökulmasta, kääntyy huomio ehkä jälleen ennenkaikkea eri oppilaiden erilaisuuteen heidän nykytilanteensa ja tähänastisen kokemuspiirinsä kannalta sekä siihen, että suurimmalle osalle heidän huoltajistaan on nuoren edessä oleva tilanne hyvin toisenlainen kuin heidän itsensä ollessa vastaavassa iässä. On ilmeistä, että perehdyttäminen edessä oleviin erilaisiin mahdollisuuksiin sekä henkilökohtaisen ohjauksen tarjoaminen ovat välttämättömiä sekä nykyisestä keskikoulusta että vielä enemmän tulevasta peruskoulusta lähteville oppilaille.

\section{Mitä tapahtuu keskikoulun jälkeen?}

Eräs lukiotutkimuksen pääongelmista on nykyiseen lukioon siirtymiseen liittyvien seikkojen selvittäminen. Alkuperäisten tutkimushenkilöi- 
den päätettyä keskikoulunkäyntinsä keväällä 1965 tiedusteltiin heidän sijoittumistaan seuraavana syksynä 1965 sekä tutkimuskoulujen kanslioista että myös kaikille henkilökohtaisesti lähetetyn postikyselyn avulla. $97.4 \%$ tutkimushenkilöistä palautti lomakkeen täytettynä, joten tästä joukosta saatua kokonaiskuvaa on pidettävä sangen tarkkana. Taulukossa 6 esitellään keskikoulua seuraavana syyslukukautena 1965 vallinnut sijoittumistilanne myös sen mukaan, missä tutkimuskoulussa henkilöt olivat edellisenä lukuvuotena olleet.

Lukioon siirtyi alkuperäisistä tutkimushenkilöistä $51.5 \%$ eli 737 henkilöä. Määrä vastaa hyvin sitä koko maan kokonaiskuvaa, joka syntyi kouluhallituksen samana vuonna kouluissa suorittamasta kyselystä siitä, miten moni aikoi pyrkiä lukioon sinä vuonna: $52.1 \% 487$ suomenkielisen oppikoulun oppilaista. Eri koulujen välillä oli huomattavia eroja, jotka paikkakuntatyypeittäin taas hyvin vastasivat em. kyselyn antamaa tietoa siitä, että Etelä-Suomessa siirrytään lukioon suhteellisesti enemmän kuin Pohjois- ja Itä-Suomessa, suurissa kaupungeissa enemmän kuin pienissä, ja näissä enemmän kuin maalaiskunnissa sijaitsevissa kouluissa sekä vihdoin kouluissa, joissa on oma lukio, enemmän kuin siellä, missä sitä ei ole. (Sysiharju 1966 a, taulut 6 ja 8) Silti jäi vielä samojen tai samanlaisten paikkakuntien koulujen välille lukioon siirtymisessä huomattavia eroavuuksia, joiden analysointi ei mahdu tähän yhteyteen.

Pojat siirtyivät lukioon suhteellisesti runsaammin kuin tytöt. Ero on tosin pieni, mutta näin suuressa joukossa havaittava ja se esiintyi samanlaisena kaikissa keskikoulun viimeisellä luokalla tehdyissä aikomusten kyselyissä ja - kuten tämänkin kirjoituksen myöhemmät taulukot osoittavat - kaikissa alaryhmityksissä. Myös keskikoulun ja lukion sukupuolijakaumat koko maassa viittaavat samaan suuntaan (Sysiharju 1966 b, 174). Lukioon siirtyneistä oli kuitenkin edelleen enemmistö (57.1 \%) tyttöjä, vaikkakin pienempänä kuin perusjoukossa V luokalla (58.3\%).

Lukioon siirtyneistä 737 henkilöstä vain 625 eli $84.8 \%$ oli samassa oppikoulussa kuin edellisenä lukuvuonna keskikoulun viimeisellä, 112 eli $15.2 \%$ oli vaihtanut koulua. Näistä ilmoitti $16 \%$ kotipaikkakunnan muuttumisen syyksi vaihtamiseen ja $29 \%$ sen, ettei entisessä koulussa ollut lukiota, yhteensä kuitenkin vain siis alle puolet syistä oli näin »ehdottomia». $38 \%$ koulua vaihtaneista ilmoitti, ettei kilpailun vuoksi ollut »mahtunut» entiseen kouluunsa, $11 \%$, ettei viihtynyt entisessä koulussa ja $7 \%$ esitti erilaisia käytännöllisiä syitä.

Toisaalta eivät myöskään omassa koulussaan lukioon siirtyneet 625 tutkimushenkilöä muodostaneet enempää kuin $73.8 \%$ näiden 11 oppikoulun VI luokista, joiden vahvuus oli kaikkiaan 847 henkeä. Samoille luokille oli siirtynyt toisten koulujen keskikouluasteelta 123 oppilasta eli $14.5 \%$ VI luokista. Lisäksi oli näillä luokilla $1965 / 66$ myös $11.7 \%$ oppilaista eli 99 henkeä toista vuotta VI luokalla. Lukioon siirryttäessä tapahtuu siis nykyoloissa suhteellisen runsaasti oppikoulun vaihtamista. 
Ta u l u k k o 6 . Tutkimuskoulujen viidesluokkalaisten sijoittuminen syksyllä 1965

Table 6. The status of the students from the last grade of Junior Secondary of the Project Schools in the following autumn 1965

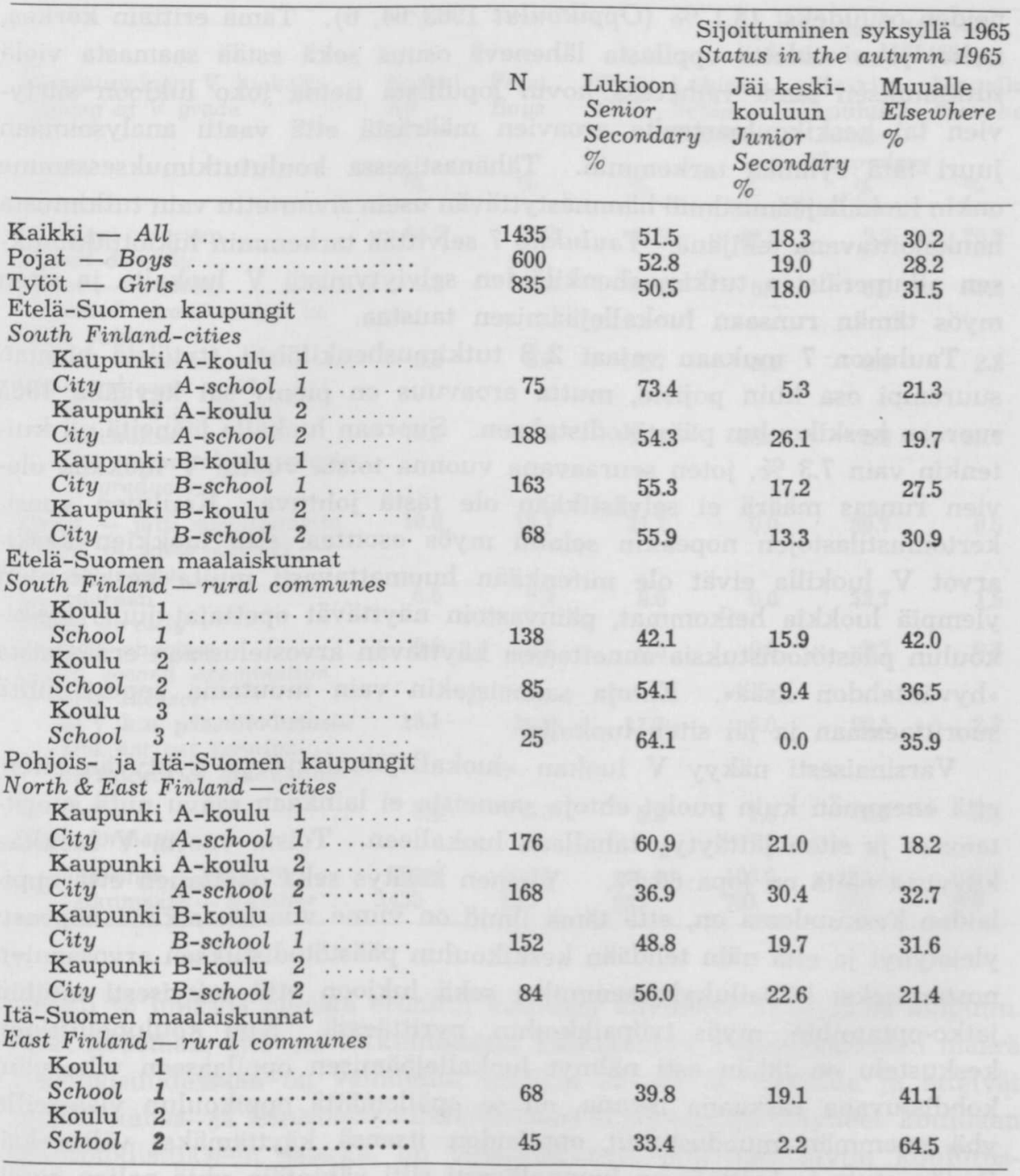

Kaikesta luonnontieteellisen koulutuksen tarpeellisuuden korostamisesta huolimatta matemaattiselle linjalle siirtyneet muodostivat vähemmistön, $44.3 \%$, lukioon siirtyneistä alkuperäisistä tutkimushenkilöistä, joista $54.5 \%$ oli mennyt kielilinjalle ja $1.2 \%$ (lähinnä muihin kouluihin siirtyneitä) muunlaiselle linjalle. Tällä kohdalla oli sukupuolten välinen eroavuus sangen merkittävä: kun pojista $77.0 \%$ oli matemaattisella, oli tytöistä vain $22.0 \%$ valinnut tämän linjan. 
Siirryttäessä lukiossa jatkavien sijasta tarkastelemaan muita keskikoulusta lähteviä on ehkä tärkein havạinto toiseksi vuodeksi V luokalle jääneiden suuri osuus: $18.3 \%$. Tutkitusta oppilasryhmästä saatu tulos vastaa kuitenkin tässäkin myös koko maan yleiskuvaa, sillä virallinen oppikoulutilasto ilmoitti 1964 keskikoulun ylimmän luokan oppilaista luokalle jääneiden osuudeksi 18.1 \% (Oppikoulut 1963/64, 6). Tämä erittäin korkea, miltei joka viidettä oppilasta lähenevä osuus sekä estää saamasta vielä tutkimuksen tässä vaiheessa kovin lopullista tietoa joko lukioon siirtyvien tai keskikouluasteelta eroavien määrästä että vaatii analysoimaan juuri tätä ryhmää tarkemmin. Tähänastisessa koulututkimuksessamme onkin luokallejäämisilmiö hämmästyttävän usein sivuutettu vain tutkimusta hankaloittavana tekijänä. Taulukko 7 selvittää tarkemmin lukiotutkimuksen alkuperäisten tutkimushenkilöiden selviytymistä V luokalta ja siten myös tämän runsaan luokallejäämisen taustaa.

Taulukon 7 mukaan vajaat $2 / 3$ tutkimushenkilöistä (tytöistä hieman suurempi osa kuin pojista, mutta eroavuus on pieni) sai keväällä 1965 suoraan keskikoulun päästötodistuksen. Suoraan luokalle jääneitä oli kuitenkin vain $7.3 \%$, joten seuraavana vuonna toista vuotta V luokalla olevien runsas määrä ei selvästikään ole tästä johtuva. Koulujen vuosikertomustilastojen nopeakin selailu myös osoittaa, että luokkien keskiarvot V luokilla eivät ole mitenkään huomattavasti muita keskikoulun ylempiä luokkia heikommat, päinvastoin näyttävät opettajat juuri keskikoulun päästötodistuksia annettaessa käyttävän arvostelussaan eräänlaista »hyväntahdon lisää». Ehtoja saaneistakin vain muutama reputti niitä suorittaessaan ja jäi siten luokalle.

Varsinaisesti näkyy V luokan »luokallejäämisvyöry» syntyvän siten, että enemmän kuin puolet ehtoja saaneista ei lainkaan saavu niitä suorittamaan ja siten jättäytyy tahallaan luokalleen. Toista vuotta V luokkaa käyvistä näitä on jopa $60 \%$. Yleinen käsitys sekä opettajien että oppilaiden keskuudessa on, että tämä ilmiö on viime vuosien aikana nopeasti yleistynyt ja että näin tehdään keskikoulun päästötodistuksen arvosanojen nostamiseksi kilpailukykyisemmiksi sekä lukioon että erityisesti muihin jatko-opintoihin, myös työpaikkoihin, pyrittäessä. Kun koulupoliittinen keskustelu on tähän asti nähnyt luokallejäämisen oppilaaseen ulkoapäin kohdistuvana raskaana iskuna, on se epäilemättä oppikoulun yläasteilla yhä enemmän muodostunut oppilaiden itsensä käyttämäksi välineeksi. Ilmiön etuja ja haittoja on luonnollisesti silti vähintäin yhtä paljon syytä tutkia (kuten tässä tutkimuksessa tullaankin tekemään), mutta kysymyksenasettelu keskustelussa olisi ehkä kuitenkin suunnattava paitsi siihen, onko opettajilla oikeus jättää oppilaita luokalle, myös siihen, onko oppilailla oikeutta tahallaan jättäytyä luokalleen.

Koulupoliittisen suunnittelun kannalta on myös tärkeä havaita, että noin $2 \%$ vielä viidennen luokan käyneistä henkilöistä itse ilmoitti jättäneensä oppikoulun saamatta V luokan päästötodistusta. Sitä paitsi 
Taulukko 7. Tutkimuskoulujen oppilaiden suoriutuminen V luokaltaan 1964/65 ja sijoittuminen seuraavana lukuvuonna (1965/66)

Table

7. Passing and failing in $V$ grade and status in the beginning of the following term $(1965 / 66)$

\begin{tabular}{|c|c|c|c|c|c|c|}
\hline \multirow{3}{*}{$\begin{array}{l}\text { Suoriutuminen V luokalta } \\
\text { Passing of V grade }\end{array}$} & \multirow{3}{*}{$\begin{array}{l}\text { Kaikki } \\
\text { All } \\
\% \\
\%\end{array}$} & \multirow{3}{*}{$\begin{array}{c}\text { Pojat } \\
\text { Boys } \\
\% \\
\end{array}$} & \multirow{3}{*}{$\begin{array}{c}\text { Tytöt } \\
\text { Girls } \\
\%\end{array}$} & \multicolumn{3}{|c|}{$\begin{array}{l}\text { Sijoittuminen } 1965 / 66 \\
\text { Status in } 1965 / 66\end{array}$} \\
\hline & & & & $\begin{array}{l}\text { Lukiossa } \\
\text { Senior } \\
\text { Secondary }\end{array}$ & $\begin{array}{l}\text { Keski- } \\
\text { koulussa } \\
\text { Junior }\end{array}$ & $\begin{array}{l}\text { Muualla } \\
\text { Elsewher }\end{array}$ \\
\hline & & & & $\%$ & $\begin{array}{c}\text { Secondary } \\
\%\end{array}$ & $\%$ \\
\hline $\begin{array}{l}\text { Selviytyi suoraan } \\
\text { Passed directly }\end{array}$ & 64.5 & 63.2 & 65.5 & 86.8 & 2.3 & 70.2 \\
\hline $\begin{array}{l}\text { Ehdot - suoritti ......... } \\
\text { Repeated examination in } \\
\text { some subject }\end{array}$ & 9.8 & 10.2 & 9.5 & 8.6 & 0.0 & 19.2 \\
\hline $\begin{array}{l}\text { Korotti arvosanan } \\
\text { Improved some mark }\end{array}$ & 2.2 & 3.0 & 1.7 & 3.1 & 0.0 & 2.3 \\
\hline $\begin{array}{l}\text { Sai V lk:n päästö- } \\
\text { todistuksen } \\
\text { Got terminal certificate } \\
\text { of graduation }\end{array}$ & 76.5 & 76.4 & 76.7 & 98.5 & 2.3 & 91.7 \\
\hline $\begin{array}{l}\text { Ehdot - jätti suorittamatta } \\
\text { Failed in some subject - } \\
\text { did not repeat }\end{array}$ & 10.9 & 10.7 & 11.2 & 0.0 & 59.7 & 0.5 \\
\hline $\begin{array}{l}\text { Jäi suoraan } \ldots \ldots \ldots \ldots \ldots \\
\text { Failed directly }\end{array}$ & 6.6 & 7.3 & 6.0 & 0.0 & 33.7 & 1.5 \\
\hline $\begin{array}{l}\text { Reputti ehdoissa } \\
\text { Failed second examination } \\
\text { in some subject }\end{array}$ & 0.6 & 0.7 & 0.5 & 0.0 & 2.7 & 0.3 \\
\hline $\begin{array}{l}\text { Ei V lk:n päästötodistusta } \\
\text { Did not get terminal } \\
\text { certificate of graduation }\end{array}$ & 18.1 & 18.7 & 17.7 & 0.0 & 96.1 & 2.3 \\
\hline $\begin{array}{l}\text { Ei tietoa } \ldots . . . \ldots \ldots \ldots \ldots \\
\text { No information }\end{array}$ & 5.4 & 5.0 & 5.8 & 1.5 & 1.6 & 6.0 \\
\hline $\begin{array}{l}\text { Yhteensä - Total \% .... } \\
\text { Lukumäärä - Number }\end{array}$ & $\begin{array}{l}100.0 \\
1435\end{array}$ & $\begin{array}{l}100.0 \\
600\end{array}$ & $\begin{array}{l}100.0 \\
835\end{array}$ & $\begin{array}{l}100.0 \\
731\end{array}$ & $\begin{array}{l}100.0 \\
264\end{array}$ & $\begin{array}{l}100.0 \\
399\end{array}$ \\
\hline
\end{tabular}

oli $1.5 \%$ luokilla olleista eronnut koulusta käymättä V luokkaa loppuun. Kun tiedetään, että eri tutkimuksissa keskikoulun keskeyttäneiden määrä kokonaisuudessaan on vaihdellut ainakin 25-29 \% vaiheilla ja etteivät kaikki kansa- ja kansalaiskoululaisetkaan suinkaan ole käyneet kouluaan päästötodistukseen saakka, on todennäköistä, että 1960-luvun koulutusyhteiskunnassa on monia nuoria, jotka lähtevät elämään ilman minkään koulumuodon antamaa päästötodistusta. Peruskoulu-uudistus pyrkii osaltaan juuri tämän torjumiseen, mutta on tuskin luultavaa, että meillä enempää kuin muuallakaan yleistä koulutustaan kehittäneissä maissa vältyttäisiin kokonaan itse koulunsa keskeyttäneiden eli »drop-out»-ongelmasta, jonka tosiasian tällä hetkellä vain koulujärjestelmämme kaksijakoisuus ja tilastojen kehittymättömyys kätkenevät tietoisuudesta.

Lukioon siirtyvistä on taulukosta 7 ehkä vielä todettava, että toista- 
T a u l uk k o 8. Lukuvuonna 1965/66 eri tavoin sijoittuneiden oppilaiden keskikouluvaiheet

Table 8. Previous school achievement of students with different status in 1965/66

\begin{tabular}{|c|c|c|c|c|c|c|}
\hline \multirow{6}{*}{$\begin{array}{l}\text { Ei luokalle, ei ehtoja } \\
\text { Passed all grades with } \\
\text { no conditions } \\
\text { Ei luokalle, ollut ehtoja ..... } \\
\text { Passed all grades, repeated } \\
\text { some subject } \\
\text { Jäänyt V luokalle ............ } \\
\text { Repeated fifth grade } \\
\text { Jäänyt luokalle } \\
\text { I-IV luokilla } \\
\text { Repeated a class during } \\
\text { I-IV grade }\end{array}$} & \multirow{3}{*}{$\begin{array}{l}\text { Kaikki } \\
\text { All } \\
44.4\end{array}$} & \multirow{3}{*}{$\begin{array}{c}\text { Pojat } \\
\text { Boys } \\
40.0\end{array}$} & \multirow{3}{*}{ 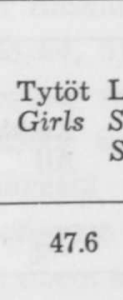 } & \multicolumn{3}{|c|}{$\begin{array}{c}\text { Sijoittuminen 1965/66 } \\
\text { Status in } 1965 / 66\end{array}$} \\
\hline & & & & $\begin{array}{l}\text { Lukiossa } \\
\text { Senior } \\
\text { Secondary }\end{array}$ & $\begin{array}{l}\text { Keski- } \\
\text { koulussa } \\
\text { yJunior } \\
\text { Secondary }\end{array}$ & $\begin{array}{l}\text { Muualla } \\
\text { Elsewhere }\end{array}$ \\
\hline & & & & 65.4 & 20.2 & 25.0 \\
\hline & 19.9 & 18.6 & 20.7 & 12.6 & 48.4 & 14.8 \\
\hline & 15.4 & 16.8 & 14.5 & 11.0 & 0.4 & 31.5 \\
\hline & 20.3 & 24.6 & 17.2 & 11.0 & 31.0 & 28.7 \\
\hline $\begin{array}{l}\text { Yhteensä-Total \% } \\
\text { Lukumäär - Number }\end{array}$ & $\begin{array}{l}100.0 \\
1435\end{array}$ & $\begin{array}{l}100.0 \\
600\end{array}$ & $\begin{array}{l}100.0 \\
835\end{array}$ & $\begin{array}{l}100.0 \\
731\end{array}$ & $\begin{array}{l}100.0 \\
264\end{array}$ & $\begin{array}{l}100.0 \\
399\end{array}$ \\
\hline
\end{tabular}

T a u lukko 9. Tutkimuskoulujen viidesluokkalaisten sijoittuminen lukuvuonna 1965/66 edellisen kevättodistuksen mukaan

Table 9. The status of the students from the last grade of Junior Secondary at the beginning of the following school term $(1965 / 66)$, by level of certificate received

\begin{tabular}{|c|c|c|c|c|c|c|c|c|c|}
\hline \multirow[b]{2}{*}{$\begin{array}{l}\text { Sijoittuminen } \\
\text { Status }\end{array}$} & $\begin{array}{r}\text { kuainei } \\
\text { un } \\
\text { un }\end{array}$ & \multicolumn{7}{|c|}{$\begin{array}{l}\text { Lukuaineiden keskiarvo lukuvuonna } 1964 / 65 \\
\text { Average mark received in 1964/65 }\end{array}$} & .00 \\
\hline & 丞華 & 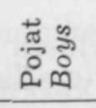 & 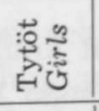 & 竎 & 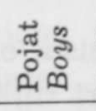 & 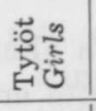 & 竎 & 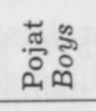 & 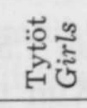 \\
\hline $\begin{array}{l}\text { Lukioon - } \\
\text { Senior Secondary ...... } \\
\text { Jäi keskikouluun - }\end{array}$ & 22.1 & 25.5 & 19.5 & 64.1 & 65.0 & 63.2 & 86.8 & 88.8 & 85.5 \\
\hline $\begin{array}{l}\text { Jäi keskikouluun - } \\
\text { Junior Secondary } \\
\text { Muualle - Elsewhere }\end{array}$ & $\begin{array}{l}46.7 \\
31.2\end{array}$ & $\begin{array}{l}47.5 \\
27.0\end{array}$ & $\begin{array}{l}46.2 \\
34.3\end{array}$ & $\begin{array}{r}2.4 \\
33.5\end{array}$ & $\begin{array}{r}2.4 \\
32.6\end{array}$ & $\begin{array}{r}2.4 \\
34.1\end{array}$ & $\begin{array}{r}0.0 \\
13.2\end{array}$ & $\begin{array}{r}0.0 \\
11.2\end{array}$ & $\begin{array}{r}0.0 \\
14.2\end{array}$ \\
\hline $\begin{array}{l}\text { Yhteensä - Total ... } \\
\text { Lukumäärä }- \text { Number }\end{array}$ & $\begin{array}{l}100.0 \\
516\end{array}$ & $\begin{array}{l}100.0 \\
219\end{array}$ & $\begin{array}{l}100.0 \\
297\end{array}$ & $\begin{array}{l}100.0 \\
585\end{array}$ & $\begin{array}{l}100.0 \\
242\end{array}$ & $\begin{array}{l}100.0 \\
343\end{array}$ & $\begin{array}{l}100.0 \\
273\end{array}$ & $\begin{array}{l}100.0 \\
108\end{array}$ & $\begin{array}{l}100.8 \\
165\end{array}$ \\
\hline $\begin{array}{l}\% \text { koko ryhmästä }- \\
\% \text { of whole group } \\
(\mathrm{N}=1374) \\
\% \text { pojista }-\% \text { of boys } \\
(\mathrm{N}=569) \\
\% \text { tytöistä }-\% \text { of girls } \\
(=805)\end{array}$ & 37.6 & 38.5 & 36.9 & 42.6 & 42.5 & 42.6 & 19.8 & 19.0 & 20.5 \\
\hline
\end{tabular}


kymmentä prosenttia heistä pääsi sinne siirtymään vain ehtoja suorittamalla ja arvosanoja korottamalla. Taulukko 8 antaa lisää tietoja sekä eri tavoin sijoittuneiden että yleensä nykyisten keskikoulua päättävien aikaisemmasta oppikouluhistoriasta.

Tämän taulukon mukaan ei puoletkaan nykyisistä viidesluokkalaisista ole selviytynyt näin pitkälle ilman luokalle jäämisiä tai ehtoja. Luokalle jäämisessä on poikien ja tyttöjen eroavuus suurin. (Toisaalta näyttää siltä, kuin tämä eroavuus pienenisi juuri V luokalle jäämisen kohdalla ja tahallaan ehtonsa suorittamatta jättäviä näytti silloin olevan hiukan enemmänkin tyttöjen kuin poikien piirissä.) Joka tapauksessa lukioonkin siirtyneistä useampi kuin joka kymmenes oli käynyt viidennen luokan kahteen kertaan (kaikista viidennellä luokalla toista vuotta olleista $39 \%$ siirtyi lukioon, siis melkoinen osa.) ja toinen runsas kymmenesosa oli aikaisemmin keskikoulun aikana jäänyt luokalleen.

Nyt V luokkaa toista kertaa käymään jääneistä kaksi kolmannesta oli aikaisemmin luokallejäämisen välttäneitä, jopa joka viides ei ollut aikaisemmin saanut ehtojakaan. On täysin mahdollista, että jos viidennen luokan kahteen kertaan käyminen on ollut tietoisena tavoitteena, joissakin tapauksissa ei ole vain tahallaan jättäydytty pois ehtojen suorittamisesta, vaan myös huolehdittu siitä, että tähän tarpeelliset ehdot on saatu.

Taulukossa on vielä syytä kiinnittää huomiota siihen, että oppikoulunsa keskikouluvaiheeseen lopettaneista jopa neljännes on selviytynyt keskikoulusta ilman luokallejäämisiä tai ehtoja. Kun muistetaan että tämä oli suhteellisen harvinaista koko joukossa ja että lukioonkin siirtyneistä tuskin kaksi kolmannesta oli näin hyvin suoriutunut, on ilmeistä, että nykyinen lukioon siirtyminen ei suinkaan merkitse kaikkien hyvien oppilaiden sinne siirtymistä. Tätä valaisee vielä tarkemmin taulukko 9 , josta näkyy, miten suuri osa eritasoisista lukuaineiden keskiarvoryhmistä siirtyi lukioon tai erosi oppikoulusta.

Lukioon pääsemistä varten vaaditaan asetuksen mukaan lukuaineiden keskiarvo, joka on vähintäin 6.50, ns. lukion kynnys. Useissa lukion karsintaa koskevissa keskusteluissa on kuitenkin epäilty alle 7 keskiarvolla lukioon siirtymisen tarkoituksenmukaisuutta. Taulukon alaosasta käy ilmi, että keskikoulun viimeisellä luokalla yhteensä 13 eri oppikoulussa yli kolmannes oppilaista sai alle 7 keskiarvon - pojat hiukan useammin kuin tytöt, mutta ero on pienehkö. Ei ole yllättävää, että tästä ryhmästä lähes puolet jäi käymään keskikoulun viimeistä luokkaa toiseen kertaan, sen sijaan on ehkä pantava merkille, että useampi kuin joka viides heistä siirtyi lukioon, pojista jopa joka neljäs. Poikien tyttöjä runsaampi lukioon siirtyminen toistuu jokaisessa keskiarvoryhmässä ylintä myöten, mutta sukupuolten välinen eroavuus on suurin juuri tässä heikoimmassa ryhmässä. Tutkimus tulee myöhemmin selvittelemään syitä lähemmin, mutta 
Ta ulukko 10. Tutkimuskoulujen oppilaiden pyrkiminen ja pääseminen lukioon ja muihin oppilaitoksiin vuonna 1965

Table 10. Applications and admissions of Junior Secondary leavers to Senior Secondary and other schools in the following year

Lukioon pyrkiminen ja pääseminen

Application and admission to Senior Secondary
Sijoittuminen 1965/66

Status in 1965/66

\begin{tabular}{|c|c|c|c|c|c|c|}
\hline & $\begin{array}{l}\vec{x} \\
\frac{\vec{x}}{\pi} \overrightarrow{\widetilde{4}} \\
\%\end{array}$ & 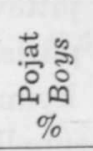 & 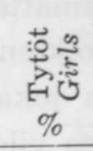 & 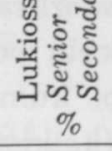 & 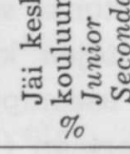 & 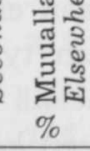 \\
\hline $\begin{array}{l}\text { Ei ole pyrkinyt }- \text { Did not apply } \\
\text { Pyrkinyt }- \text { pääsi }- \text { aloitti }\end{array}$ & 42.6 & 41.5 & 43.5 & 0.0 & 97.0 & 88.0 \\
\hline $\begin{array}{c}\text { Applied - admitted - entered } \\
, \quad \text { - ei päässyt ensin - aloitti }\end{array}$ & 47.0 & 47.7 & 46.5 & 92.1 & 0.0 & 0.0 \\
\hline $\begin{array}{l}- \text { first not admitted - then } \\
\text { entered }\end{array}$ & 2.4 & 2.5 & 2.4 & 4.8 & 0.0 & 0.0 \\
\hline $\begin{array}{l}\text { - } \quad \text { - ei päässyt - not admitted } \\
\text { - pääsi - ei mennyt }\end{array}$ & 0.7 & 0.8 & 0.6 & 0.0 & 0.8 & 2.0 \\
\hline $\begin{array}{l}\text { - admitted - did not enter } \\
\text { - pääsi - ei mennyt - nyt } \\
\text { on kuitenkin }\end{array}$ & 1.8 & 1.5 & 2.0 & 0.0 & 0.4 & 5.5 \\
\hline $\begin{array}{r}\text { - admitted - did first not } \\
\text { enter - entered then ... }\end{array}$ & 0.9 & 1.3 & 0.6 & 1.8 & 0.0 & 0.0 \\
\hline $\begin{array}{l}\text { Pyrkineitä yhteensä } \\
\text { Total number of applicants } \\
\text { Ei tietoa - No information }\end{array}$ & $\begin{array}{r}52.8 \\
4.6\end{array}$ & $\begin{array}{r}53.8 \\
4.7\end{array}$ & $\begin{array}{r}52.1 \\
4.4\end{array}$ & $\begin{array}{r}98.7 \\
1.3\end{array}$ & $\begin{array}{l}1.2 \\
1.8\end{array}$ & $\begin{array}{l}7.5 \\
4.5\end{array}$ \\
\hline $\begin{array}{l}\text { Yhteensä - Total \% ... } \\
\text { Lukumäärä }- \text { Number }\end{array}$ & $\begin{array}{l}100.0 \\
1435\end{array}$ & $\begin{array}{l}100.0 \\
600\end{array}$ & $\begin{array}{l}100.0 \\
835\end{array}$ & $\begin{array}{l}100.0 \\
731\end{array}$ & $\begin{array}{l}100.0 \\
264\end{array}$ & $\begin{array}{l}100.0 \\
399\end{array}$ \\
\hline
\end{tabular}

Muihin oppilaitoksiin pyrkiminen ja pääseminen

Applications and admissions to other schools

Ei ole pyrkinyt - Did not apply .... Pyrkinyt - pääsi — aloitti

Applied - admitted - entered

- ei päässyt ensin - on toisessa - not admitted - entered another ......

- ei päässyt - on oppikoulussa - not admitted is in secondary school ..

- ei päässyt - ei opiskele not-admitted - not studying ...............

- pääsi - ei mennyt - on toisessa - admitted did not enter - entered

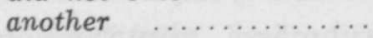

- pääsi - ei mennyt - on oppikoulussa - admitted - did not enter - in secondary school ........

$\begin{array}{rrrrrr}68.1 & 66.8 & 69.0 & 85.6 & 71.6 & 39.6 \\ 5.8 & 3.7 & 7.3 & 0.0 & 0.0 & 20.1 \\ 1.0 & 1.5 & 0.6 & 0.0 & 0.0 & 1.0 \\ 2.3 & 3.5 & 1.4 & 4.1 & 1.1 & 0.0 \\ 3.1 & 4.3 & 2.3 & 0.0 & 0.0 & 11.0 \\ & & & & & \\ 0.3 & 0.2 & 0.4 & 0.0 & 0.0 & 1.0 \\ & & & & & \\ 0.4 & 0.7 & 0.1 & 0.7 & 0.0 & 0.0\end{array}$


- pääsi - ei mennyt - ei
opiskele
admitted - did not enter
- not studying $\ldots . . . .$.

Pyrkineitä yhteensä

Total number of applicants ..............................

Ei tietoa - No information .............

Yhteensä - Total \% .............

Lukumäärä - Number ............

$\begin{array}{rrrrrr}0.5 & 0.5 & 0.5 & 0.0 & 0.0 & 1.8 \\ & & & & & \\ 13.3 & 14.3 & 12.6 & 4.8 & 1.9 & 37.4 \\ 18.6 & 18.8 & 18.4 & 9.5 & 27.4 & 23.0 \\ 100.0 & 100.0 & 100.0 & 100.0 & 100.0 & 100.0 \\ 1435 & 600 & 835 & 731 & 264 & 399\end{array}$

on ehkä jo tässä yhteydessä muistutettava tyttöjen tosiasiallisesta enemmistöstä keskikoulun päättyessä ja siitä mahdollisuudesta, että opiskeluhaluttomat ja -taipumuksettomat pojat ovat ehkä jo aikaisemmin keskeyttäneet, vastaavat tytöt taas runsaammin pysyneet "matkassa" tänne saakka, mutta ei enää edemmäs.

Lukioon siirtymisen yleisyys kasvaa kyllä - odotusten mukaisesti - keskiarvon noustessa, mutta on kuitenkin huomattava, että yli 8.00 lukuaineiden keskiarvoksi saaneista, joille usein oltaisiin varmaan valmiita lukiota suosittelemaan, kuitenkin selvästi toistakymmentä prosenttia erosi oppikoulusta keskikouluvaiheessa, tässäkin tytöistä selvästi suurempi osa kuin pojista.

Kaikki edelliset tarkastelut ovat osoittaneet toisaalta ainakin joka toisen keskikoulunsa lopettaneista siirtyneen lukioon 1960-luvulla, toisaalta ettei tämän siirtymisen yhteys aikaisempaan koulusuoriutumiseen, vaikkakin se selvästi on olemassa, silti ole ollut voimakkaan yksiselitteistä. Asiaan vaikuttavat epäilemättä monet seikat, joista erääseen, muiden oppilaitosten lukion rinnalle tarjoamiin mahdollisuuksiin, kiinnitetään huomiota taulukossa 10.

Taulukko antaa tietoja oppilaiden vastauksista, kun heiltä keskikoulun päättymistä seuraavana syksynä tiedusteltiin toisaalta, olivatko he pyrkineet lukioon ja miten tällöin oli käynyt, sekä toisaalta, olivatko pyrkineet muihin oppilaitoksiin sekä miten tässä oli käynyt. Lukioon ilmoitti kaikkiaan vain hiukan suurempi osa pyrkineensä kuin mikä siellä lopulta syksyllä oli. 758 lukioon pyrkimisestään tietoja antaneesta henkilöstä oli sinne ensin päässyt $94.1 \%$ ja pääsemättä jäänyt $5.9 \%$. Sangen suuri osa pyrkineistä pääsi siis heti, mutta karsituistakin tutkimushenkilöistä $78 \%$ pyrki vielä toiseen lukioon ja pääsi sinne. Toisaalta lukioon jo otetuistakin monet eivät heti menneetkään tai ilmoittaneet menevänsä, osa tosin meni myöhemmin, mutta osa jäi lopultakin lukion ulkopuolelle.

Lopputuloksena voidaan todeta, että $95.4 \%$ edellämainituista lukioon pyrkimisestään tietoja antaneista myös meni lopulta lukioon. Luvut vastaavat hyvin 11 tutkimuskoulun kanslioiden antamia tietoja, joiden mukaan niihin kaikkiaan otettiin 93.6 \% lukioasteelle pyrkineistä 95.7 \% omasta koulusta pyrkineistä ja $84.9 \%$ muista kouluista pyrkineistä. Samoin koko maassa rehtorit ilmoittivat kouluhallitukselle 1962 
T a ulukko 11. Tutkimuskoulujen oppilaiden sijoittuminen oppikoulun ulkopuolelle syksyllä 1965

Table 11. Placement of Junior Secondary leavers outside secondary school in the following year 1965

\begin{tabular}{|c|c|c|c|}
\hline t & $\begin{array}{l}\text { Kaikki } \\
\text { All } \\
\%\end{array}$ & $\begin{array}{c}\text { Pojat } \\
\text { Boys } \\
\%\end{array}$ & $\begin{array}{c}\text { Tytöt } \\
\text { Girls } \\
\%\end{array}$ \\
\hline $\begin{array}{l}\text { Ei tietoa }- \text { No information } \ldots \ldots \ldots \ldots \ldots \ldots \ldots \ldots \ldots \ldots \ldots \\
\text { Opiskelee }- \text { ei oppikoulussa }\end{array}$ & 1.9 & 1.7 & 2.1 \\
\hline $\begin{array}{l}\text { Studying - other than secondary school .............. } \\
\text { Harjoittelee ammattioppilaitosta varten }\end{array}$ & 7.2 & 5.7 & 8.4 \\
\hline $\begin{array}{l}\text { Apprentice in order to get into vocational school .... } \\
\text { Ansiotyö - toivoo saavansa ammatin sitä }\end{array}$ & 7.9 & 10.0 & 6.4 \\
\hline $\begin{array}{l}\text { Employed - hopes to get permanent occupation ....... } \\
\text { Ansiotyö - väliaikainen, rahan vuoksi }\end{array}$ & 1.3 & 0.7 & 1.8 \\
\hline Employed - for financial reasons, temporary ........ & 5.8 & 4.8 & 6.5 \\
\hline $\begin{array}{l}\text { Kotona }- \text { At home } \\
\text { Asevelvollisena }- \text { In military service } \ldots \ldots \ldots \ldots \ldots\end{array}$ & $\begin{array}{l}4.6 \\
0.8\end{array}$ & $\begin{array}{l}3.0 \\
1.8\end{array}$ & 5.8 \\
\hline Ulkomailla - Abroad ............................ & 0.5 & 0.3 & 0.6 \\
\hline Sairaana - Sick ........................ & 0.1 & 0.1 & 0.1 \\
\hline 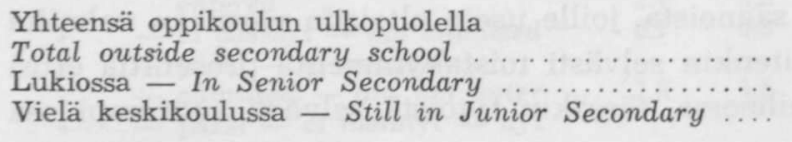 & $\begin{array}{l}28.3 \\
51.5 \\
18.3\end{array}$ & $\begin{array}{l}26.5 \\
52.8 \\
19.0\end{array}$ & $\begin{array}{l}29.4 \\
50.5 \\
18.0\end{array}$ \\
\hline $\begin{array}{l}\text { Yhteensä - Total } \\
\text { Lukumäärä }- \text { Number }\end{array}$ & $\begin{array}{l}100.0 \\
1435\end{array}$ & $\begin{array}{l}100.0 \\
600\end{array}$ & $\begin{array}{l}100.0 \\
835\end{array}$ \\
\hline
\end{tabular}

94.1 \% lukioon pyrkineistä tulleen otetuksi. Todella karsituiksi jääneiden lukioon pyrkineiden määrä jäi alle puoleen niistä, jotka itse muuttivat mieltään ja päättivät jäädä lukion ulkopuolelle. Lukuunottamatta ns. »lukion kynnys» -keskiarvovaatimuksen (sen alle jäi $18 \%$ tutkimushenkilöistä) ja runsaan luokallejäämisen (koskee pääasiallisesti samoja) aiheuttamia rajoituksia, jotka siis lähinnä vain myöhästyttävät, on 1960-luvun Suomessa ollut suhteellisen helppo päästä lukioon, varsinkin mikäli on ollut mahdollisuuksia ja halua tarvittaessa vaihtaa koulua ja ehkä paikkakuntaakin.

Sangen toisin on vaihtoehtoina olevien muiden oppilaitosten laita. Niihin ilmoitti koko joukosta pyrkineensä $13.3 \%$ eli 191 henkilöä, oppikoulusta eronneistakin ilmoitti vain $37.4 \%$ pyrkineensä muihin oppilaitoksiin. Voidaan ajatella, että vaadittavan harjoittelun puuttuminen, liian alhainen ikä tai arvelu, että ansiot eivät riittäisi kilpailussa, olisivat olleet esteenä pyrkimiselle. Tällöin odottaisi toisaalta pyrkineiden menestyneen pääsyssä kohtalaisen hyvin. Kuitenkin vain $51.8 \%$ muuhun oppilaitokseen pyrkineestä oli sinne heti päässyt ja $48.2 \%$ tullut karsituksi. Näistä karsituista $15.2 \%$ pyrki ja pääsi toiseen oppilaitokseen, $35.8 \%$ (siis yli kaksinkertainen määrä) meni oppikouluun (lukioon tai käymään V luokkaa uudelleen) ja jokseenkin puolet $(49 \%)$ pyrkineistä ja karsituista ei keskikoulusta lähtöään seuraavana syksynä opiskellut missään. Toisaalta 
näkyy tämänikäisen nuorison ailahtelevaisuus siitä, että vain $88 \%$ muihin oppilaitoksiin alkuaan otetuista niihin myös todella meni (heistäkin muutama toiseen kuin alkuaan), $5 \%$ heistä siirtyi sittenkin oppikouluun ja $7 \%$ jäi kaikkien oppilaitosten ulkopuolelle. Lopputulokseksi jäi, että mainituista 191 muihin oppilaitoksiin pyrkineistä kaikkiaan $52.9 \%$ niihin lopulta meni. Lukioon pääsyyn verrattuna siis mahdollisuudet olivat huomattavasti heikommat, mikä ei voine olla vaikuttamatta lukioon pyrkimisen määrään.

Taulukko 11 antaa jonkinlaista kuvaa siitä, missä olivat keskikoulua seuraavana syksynä ne oppilaat, jotka olivat oppikoulunkäyntinsä päättäneet.

Voidaan ehkä sanoa, että sijoittumisestaan tietoa antaneet oppilaat ryhmittyivät neljään melko samansuuruiseen osaan: 1) oppilaitoksissa opiskeleviin, 2) harjoittelemassa oleviin, 3) ansiotyössä oleviin sekä 4) muihin vaihtoehtoihin. Vain hiukan suurempi osa pojista kuin tytöistä kuului ammattiin määrätietoisimmin valmistautuviin, siis joko oppilaitoksessa tai harjoittelemassa oleviin. Näyttää kuitenkin siltä, että tytöt olivat suuremmassa määrin jo tässä vaiheessa päässeet oppilaitoksiin, pojat taas olivat suuremmassa määrin harjoittelemassa. Enemmistö ansiotyössä olevista arveli olevansa vain rahan vuoksi ja väliaikaisesti, ansiotyössä olevista tytöistä kuitenkin joka viides, pojista paljon harvempi, toivoi saavansa siitä itselleen myös ammatin. Eri syistä pelkästään kotiin jääneiden osuus koko ryhmästä oli sangen pieni, kaikista sijoittumisestaan ilmoittaneistakin vain noin $16 \%$.

Taulukossa 12 on oppilaitoksissa, harjoittelemassa ja ansiotyössä olevat edellisenä keväänä keskikoulusta lähteneet oppilaat ryhmitetty ammattialoittain. Valtaosa eli noin kolme neljännestä koko joukosta oli toisaalta teollisuus- ja käsityö-, toisaalta myynti- ja konttorialoilla, muiden jäädessä vain pieniksi ryhmiksi. Teollisuuden ja käsityön piirissä olevia oli runsaimmin oppilaitoksissa tai harjoittelemassa olevien piirissä, myyntija konttorialoilla olevia oli taas runsaasti ansiotyössä olevissa, mikä ehkä viittaisi näiden kahden ammattialan asettamiin erilaisiin vaatimuksiin ja tarjoamiin mahdollisuuksiin välittömästi keskikoulunsa päättäville nuorille. Jokseenkin $60 \%$ pojista oli keskittynyt teollisuus- ja käsityöaloille, kun taas tyttöjen voidaan ehkä sanoa tässä ryhmittyneen useammanlaisille aloille. Näyttää kuitenkin siltä, että monipuolisuus on osittain seurausta väliaikaiseksi tarkoitetusta ansiotyöstä, josta myöhemmin aiotaan siirtyä muualle.

Sekä oppikoulussa olevien että oppikoulusta pois siirtyneiden oppilaiden tarkastelu on osoittanut, että keskikoulun viimeisellä luokalla olleiden oppilaiden sijoittuminen oli seuraavana syksynä vielä monessa suhteessa väliaikaisen luonteista. Oppilailta tiedusteltiinkin syksyn 1965 kyselyssä myös, mitä he arvelivat sijoittumisestaan seuraavana luku- 
$\mathrm{T} \mathrm{a} \mathrm{u} \mathrm{lukko} \mathrm{12.} \mathrm{Oppikoulusta} \mathrm{pois} \mathrm{siirtyneiden} \mathrm{oppilaiden} \mathrm{sijoittuminen}$ syksyllä 1965 eri oppilaitoksiin ja ammattialoille

Table 12. Distribution of the students having left secondary school to different occupational fields

\begin{tabular}{|c|c|c|c|c|c|c|c|c|}
\hline $\begin{array}{l}\text { Oppilaitos- ja } \\
\text { ammattiala } 1 \\
\text { Institute and } \\
\text { profession }\end{array}$ & $z$ & 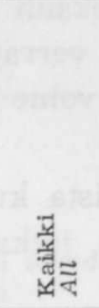 & 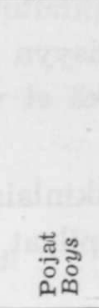 & 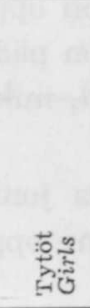 & 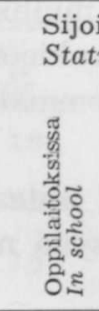 & 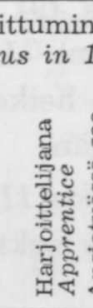 & 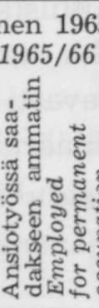 & 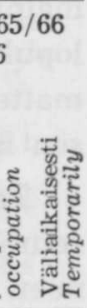 \\
\hline Per & $\%$ & $\%$ & $\%$ & $\%$ & $\%$ & $\%$ & $\%$ & $\%$ \\
\hline $\begin{array}{l}\text { General education } \\
\text { Maa- ja metsätalous - }\end{array}$ & 7 & 2.3 & 2.4 & 2.2 & 7.1 & 0.0 & 0.0 & 0.0 \\
\hline $\begin{array}{l}\text { Agriculture and forestry } \\
\text { Teollisuus ja käsityö - }\end{array}$ & 11 & 3.6 & 7.2 & 1.1 & 1.0 & 3.6 & 0.0 & 7.4 \\
\hline $\begin{array}{l}\text { Industry and handicrafts ......... } \\
\text { Myynti- ja konttori - }\end{array}$ & 121 & 39.3 & 59.2 & 25.8 & 42.4 & 45.4 & 25.0 & 29.6 \\
\hline $\begin{array}{l}\text { Sales and clerical ............... } \\
\text { Liikenne, suojelu - }\end{array}$ & 108 & 35.1 & 22.4 & 43.6 & 39.4 & 26.0 & 62.5 & 37.0 \\
\hline $\begin{array}{l}\text { Transport, protection } \\
\text { Terveyden ja sairaanhoito - }\end{array}$ & 6 & 1.9 & 4.8 & 0.0 & 0.0 & 0.0 & 12.5 & 5.0 \\
\hline Nursing, health & 26 & 8.4 & 0.0 & 14.2 & 0.0 & 21.4 & 0.0 & 2.5 \\
\hline $\begin{array}{l}\text { Talousala - Home economics ... } \\
\text { Yhteiskunnallinen työ, taide - }\end{array}$ & 21 & 6.8 & 0.0 & 11. & 7.1 & 2.7 & 0.0 & 13.6 \\
\hline $\begin{array}{l}\text { rk, arts } \\
- \text { No informatic }\end{array}$ & 4 & 1. & 0.8 & 1.6 & 3.0 & 0.9 & 0.0 & 0.0 \\
\hline - No information & & 1.3 & & & & & & 4.9 \\
\hline $\begin{array}{l}\text { Yhteensä - Total } \\
\text { Lukumäärä - Number }\end{array}$ & 308 & $\begin{array}{l}100.0 \\
308\end{array}$ & $\begin{array}{l}100.0 \\
125\end{array}$ & $\begin{array}{l}100.0 \\
183\end{array}$ & $\begin{array}{c}100.0 \\
99\end{array}$ & $\begin{array}{l}100.0 \\
112\end{array}$ & $\begin{array}{c}100.0 \\
16\end{array}$ & $\begin{array}{c}100.0 \\
81\end{array}$ \\
\hline
\end{tabular}

1 Oppilaitosten ja ammattialojen luokittelu kulkulaitosten ja yleisten töiden ministeriön ammatinvalinnanohjaustoimiston käyttämä (esim. Koulut ja kurssit 1966)

Classified according to the classification used by the Ministry of Labor

vuonna 1966/67. Taulukko 13 antaa tietoja eri ryhmien tähän antamista vastauksista.

Jokseenkin yhtä suuri osa alkuperäisistä tutkimushenkilöistä arveli olevansa lukiossa seuraavana lukuvuonna kuin oli parhaillaan kulumassa olevanakin. Tarkempi analysointi osoittaa kuitenkin, että tässä on kysymys osittain eri henkilöistä. Lukioon siirtyminen ei ilmeisesti alunperinkään ole ollut kaikkien kohdalla pysyväksi ratkaisuksi tarkoitettu, koska jo samana syksynä noin joka kahdeskymmenes eli $5 \%$ lukiossa juuri opintonsa aloittaneista arveli olevansa seuraavana lukuvuonna jossain muualla kuin lukiossa, useimmissa tapauksissa muussa oppilaitoksessa. Toisaalta keskikoulun viimeistä luokkaa toiseen kertaan käymään jääneistä yli neljännes suunnitteli siirtymistä lukioon tämän jälkeen.

Näistä molemmista ryhmistä on jo saatavissa tietoja siitä, miten seuraavana vuonna tosiasiallisesti kävi. Lukioon siirtyneistä alkuperäisistä 
T a u lukko 13. Oppilaiden syksyllä 1965 esittämät arvelut sijoittumisestaan seuraavana vuonna 1966/67

Table 13. Expectations of students in the fall of 1965 concerning their status in the following year 1966/67

\begin{tabular}{|c|c|c|c|c|c|c|}
\hline \multirow[b]{2}{*}{$\begin{array}{l}\text { Sijoitusarvelu } 66 / 67 \\
\text { Expectation }\end{array}$} & \multirow[b]{2}{*}{ 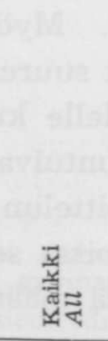 } & \multirow[b]{2}{*}{$\begin{array}{ll}\frac{\pi}{0} \\
0\end{array}$} & \multirow[b]{2}{*}{ 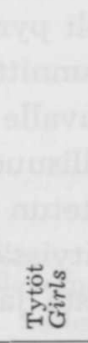 } & \multicolumn{3}{|c|}{$\begin{array}{l}\text { Sijoittuminen } \\
1965 / 66 \\
\text { Status in } \\
1965 / 66\end{array}$} \\
\hline & & & & 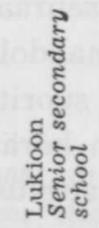 & 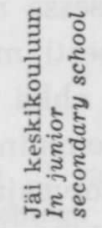 & 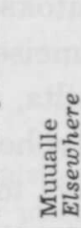 \\
\hline & $\%$ & $\%$ & $\%$ & $\%$ & $\%$ & $\%$ \\
\hline $\begin{array}{l}\text { Lukiossa - In Senior Secondary ............ } \\
\text { Muussa oppilaitoksessa - In other school }\end{array}$ & 51.7 & 54.0 & 50.0 & 91.5 & 26.5 & 0.8 \\
\hline $\begin{array}{l}\text { Muussa oppilaitoksessa - In other school ... } \\
\text { Harjoittelu ammattioppilaitosta varten - }\end{array}$ & 20.1 & 15.7 & 23.4 & 3.2 & 30.3 & 46.6 \\
\hline $\begin{array}{l}\text { Apprentice in order to get into vocational } \\
\text { school } \\
\text { Ansiotyössä, josta toivoo ammattia - }\end{array}$ & 8.7 & 10.0 & 7.8 & 0.7 & 18.9 & 17.5 \\
\hline 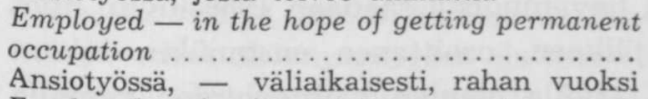 & 2.6 & 0.7 & 4.8 & 0.3 & 2.3 & 7.5 \\
\hline Employed - for financial reasons, temporary & 4.1 & 1.7 & 5.9 & 0.1 & 8.3 & 8.8 \\
\hline Kotona - At home & 0.8 & 1.2 & 0.5 & 0.0 & 1.5 & 1.8 \\
\hline Muu vastaus - Other & 5.2 & 10.7 & 1.3 & 0.7 & 7.6 & 12.8 \\
\hline Ei tietoa - No information $\ldots \ldots \ldots \ldots \ldots$ & 6.7 & 6.2 & 7.1 & 3.6 & 4.6 & 4.8 \\
\hline Yhteensä $\%-$ Total $\%$............... & 100.0 & 100.0 & 100.0 & 100.0 & 100.0 & 100.0 \\
\hline Lukumäärä - Number .. & 1435 & 600 & 835 & 731 & 264 & 399 \\
\hline
\end{tabular}

tutkimushenkilöistä erosi lukion ensimmäisen vuoden aikana noin $9 \%$, heistä suurin osa saamatta VI luokan todistusta. Mikäli heidän lisäkseen otetaan huomioon samoille luokille muista kouluista tulleet ja luokkaa toista vuotta käymään jääneet oppilaat, kohoaa lukion ensimmäiseltä luokalta eronneiden määrä yli kymmeneen prosenttiin. Tätä luokkaa pitävät monet oppilaat ilmeisesti toisaalta kokeiluna siitä, mitä lukio on, toisaalta suunnitellusti väliportaana muihin oppilaitoksiin siirryttäessä.

Toisaalta myös etukäteisarvelua useammat keskikoulun viimeisen luokan toiseen kertaan käyneistä pyrkivät ja pääsivät seuraavana vuonna lukioon, sillä lukuvuonna 1966/67 heistä noin $30 \%$ ilmoitettiin olevan lukion ensimmäisellä luokalla, tässäkin jälleen suhteellisesti huomattavasti useamman pojan kuin tytön. Luokan toiseen kertaan käymistä on siis selvästi käytetty myös lukioon pääsyä tai siellä opiskelua helpottavana tekijänä.

Toisaalta on todettava, että sittenkin useampi V luokkaa toiseen kertaan käymään jääneistä, jokseenkin puolet koko ryhmästä, suunnitteli seuraavana vuonna olevansa ammatillisessa oppilaitoksessa tai sitä varten harjoittelemassa ja että enemmistöllä siis luokan toiseen kertaan käyminen palveli muuta tavoitetta kuin lukioon pyrkimistä. 
Ammatillisten oppilaitosten osuus oli muutenkin seuraavaa vuotta koskevissa arveluissa huomattavasti suurempi kuin kuluvan vuoden tilanteessa. Niissä opiskelemista suunnitteli kolme kertaa suurempi osa ryhmästä kuin mitä niissä nyt oli ja miltei kaksi kertaa niin suuri osa kuin niihin nyt oli pyrkinyt. Myös oppikoulusta jo heti keskikoulun jälkeen eronneet suunnittelivat suuremmassa määrin opiskelua muussa oppilaitoksessa seuraavalle vuodelle kuin heistä nyt oli niihin pyrkinytkään. Ilmeisesti mahdollisuudet tuntuivat seuraavana vuonna nykyistä paremmilta, ehkä suoritetun harjoittelun, ehkä vain lisääntyneen iänkin vuoksi. Myöhemmin kerätyissä tiedoissa selvitetään, missä määrin tässä oli kysymys toiveajattelusta ja missä määrin todellisista suunnitelmista ja niiden toteuttamisesta.

Molempien sukupuolten suunnitelmien välillä oli jonkin verran eroavuuksia, jotka ehkä eniten näkyivät poikien voimakkaampana suuntautumisena lukioon, tyttöjen taas ammatillisiin oppilaitoksiin ja välittömään ansiotyöhön, josta he usein toivoivat itselleen pysyvää ammattiakin.

Yleiskuva, mikä tässä esitetyistä havainnoista saadaan 1960-luvun nuorison sijoittumisesta keskikoulun jälkeen, osoittanee ensinnäkin lukion nykyisen ylivoimaisuuden muiden tarjolla olevien vaihtoehtojen rinnalla sekä mitä tulee sinne pyrkimisen määriin että sinne pääsemisen helppouteen. Toisaalta on muistettava eri paikkakuntien ja saman paikkakunnankin eri koulujen välillä vallitsevan lukioon siirtymisessä huomattavia eroavuuksia.

Lukioon siirtymistä ei toisaalta aikaisempi melko heikko koulumenestys näytä suurestikaan ehkäisevän eivätkä toisaalta suinkaan kaikki keskikouluvaiheessa hyvin tai parhaitenkaan menestyneet oppilaat ole sinne siirtymässä. Muilla tekijöillä, joita tässä tutkimuksessa myöhemmin selvitetään, on ilmeisesti koulumenestyksen rinnalla paljon yhteyttä lukioon siirtymiseen.

Runsas tahallinen keskikoulun viimeisen luokan kertaaminen osoittanee, miten yksilöt pyrkivät käyttämään kulloinkin vallitsevan institutionaalisen järjestelmän tarjoamia mahdollisuuksia hyväkseen, usein toisinkin kuin mihin järjestelyä luotaessa on pyritty. Samaa osoittanee runsas kokeileva tai alunperinkin ehkä väliaikaiseksi tarkoitettu lukioon siirtyminen pikaisine eroamisineen sekä yleensä monenlainen »mielensä muuttaminen» päätöksissä. Uusia järjestelmiä luotaessa olisi ehkä toisaalta pyrittävä selvittämään tällaisten yksilöllisten ratkaisujen tarkoituksenmukaisuutta ja toivottavuutta, toisaalta varauduttava siihen, että samat pyrkimykset pukeutuvat uusissa järjestelmissä ehkä uusiin muotoihin.

Esitetyt tosiasiat lienevät myös vakuuttavasti osoittaneet, ettei suomalaisten uusien ylioppilaiden tyttöenemmistö ainakaan johdu tyttöjen poikia suuremmasta pyrkimisestä tai pääsemisestä lukioon. Selvästi juuri pojat 
siirtyvät tyttöjä runsaammin lukioon heikoinkin keskikoulumenestyksin. Tutkimuksen asiaksi jää edelleen selvittää, miten suuressa määrin pojat ehkä lukiossa parantavat menestymistään. Sekä peruskoulun että lukioasteen koulun uudistukset saattavat myös perusteellisesti muuttaa kummankin sukupuolen koulutietä.

\section{Kirjallisuus}

Härnqvist, Kjell-Grahm, Åke. Vägen genom gymnasiet. Elevernas syn på valsituationer och studieformer. 1960 års gymnasieutredning I. Statens offentliga utredningar 1933: 15. Stockholm 1933.

Keskikoulumenestystä koskeva tutkimus 1958. Helsingin kaupungin tilastotoimisto. Tilastollisia kuukausitietoja Helsingistä 11,1960 , n:o 5 .

Kiviluoto, Hillevi. Oppikoulumenestysprognoosin kontrollista I. Helsinki 1956. Oppikoulumenestysprognoosin kontrollista II. Turku 1959.

Nieminen, Armas. Yhteiskuntaluokat. Oma Maa 4, 92-100. 1958.

Oppikoulut 1963/64, 1964/65. Suomen virallinen tilasto IX: 81, 82. Helsinki 1966, 1967.

Palmgren, Kai. Kehittyneisyyden alueittaisista eroavuuksista Suomessa. Valtakunnansuunnittelutoimiston julkaisusarja A: 15. Helsinki 1954.

Rauhala, Urho. Yhteiskuntaluokka. Yhteiskuntatieteiden käsikirja 1006-1011. Keuruu 1964.

Riihinen, Olavi. Teollistuvan yhteiskunnan alueellinen erilaistuneisuus. Helsinki 1965.

Sandven, Johs.-Sysiharju, Anna-Liisa (toim.) Veien til og gjennom gymnaset i de nordiske land. Oslo 1967.

Specialutredningar om gymnasiet. Statens offentliga utredningar 1963:41. Stockholm 1963.

Suomen tilastollinen vuosikirja 1965. Helsinki 1966.

Sysiharju, Anna-Liisa. Kenestä tulee ylioppilas? Suomalaisen lukionkäynnin problematiikkaa. Kasvatusopillinen aikakauskirja 1966, CIII, 112-167.

Sysiharju, Anna-Liisa. Mietteitä suomalaisnuorísosta opintiellä. Sosiologia 1956, 170177.

Sysiharju, Anna-Liisa. Vägen till och genom gymnasiet i Finland. 1967. (Sandven \& Sysiharju, Veien til... ss. 18-45).

Sysiharju, Anna-Liisa. Vägen till och genom gymnasiet i de nordiska länderna. Jämförande diskussion. 1967. (Sandven \& Sysiharju, Veien til...ss. 90-102)

Sysiharju, Anna-Liisa. The way into and through gymnas in the Scandinavian countries. A comparative discussion. 1967. (Sandven \& Sysiharju, Veien til... 103-115).

Sysiharju, Anna-Liisa. The Finnish Senior Secondary Research Project. I. General presentation of the project and its original subjects. Research Bulletin No 17 from the Institute of Education, University of Helsinki 1967. (Dupl.)

Sysiharju, Anna-Liisa. The Finnish Senior Secondary Research Project. II. Departure from Junior Secondary and Transfer to Senior Secondary. Research Bulletin No 18 from the Institute of Education, University of Helsinki 1967. (Dupl.)

Waris, Heikki. Suomalaisen yhteiskunnan rakenne. Helsinki. 1948, 1952.

Yleinen väestölaskenta 1960. II. Suomen virallinen tilasto VI C: 103 (Tilastollisen päätoimiston julkaisemattomat taulukot). 


\section{Summary:}

\section{A Preliminary Report on the Finnish Senior Secondary School Research Project.}

By ANNA-LIISA SYSIHARJU, Institute of Education, University of Helsinki.

The Finnish research project "Senior Secondary" ("Gymnasieundersökningen," sLukiotutkimus") is connected with the immediate needs and questions arising from the reform plans of the Finnish school system as well as with parallel projects in other Scandinavian countries. It aims to describe and analyze the careers and development of a cohort of pupils and its individual members during the period corresponding to the normal movement of an individual through the Senior Secondary School level, that is, from the completion of the Junior Secondary School up to the Matriculation Examination. The project is especially concerned with the factors related to the choice between Senior Secondary School and other alternatives at the completion of the Junior Secondary School, on the one hand, and with the factors related to the achievement and development of students during the Senior Secondary School years, on the other. ${ }^{1}$ )

The group of original subjects consisted of 1435 pupils, i.e. all those who were finishing the last grade of the Junior Secondary School during the 1964/65 school year in 13 different secondary schools. These schools were selected to be representative of Finnish secondary schools in general and of different socioeconomic regions of Finland in particular. As a result, the occupational distribution of the primary guardians of all pupils in these schools corresponds rather well to the occupational distribution of the primary guardians of all Finnish secondary school students with the exception of a slight underrepresentation of farmers (16\% instead of $21 \%$ ). Thus it seems that the sample, about $4 \%$ of all students in the last grade of Junior Secondary in that year, could at least indicate some general traits of those students.

The first conspicuous characteristic was the high proportion of girls among the leavers, $58.3 \%$. A majority of girls is characteristic of the whole Finnish secondary school, but it seems to get intensified at the end of Junior Secondary and then to weaken by the transfer to the Senior Secondary School. A greater proportion of the boys $(52.8 \%)$ than girls $(50.5 \%)$ had in the next year transferred to the Senior Secondary. This difference in educational choice was not, however, strong enough to abolish the existing majority of girls, although it diminished it. Thus the proportion of girls in the first year of Senior Secondary was $57.1 \%$ in the sample.

The age distribution of the pupils in the last grade of Junior Secondary School ranged from 14 to 19 years. Only $44 \%$ were born in the normal, year of 1949. The lange proportion of sover-age, students was partly, (for $32 \%$ of all subjects) due to delayed transfer from the primary school, and this was especially true for the girls. It was also partly (for $36 \%$ of all subjects) due to a repeating of the grades during the Junior Secondary years, especially among the boys.

1 The Finnish Senior Secondary School Research Project is continued as a followup study of the factors related to the careers of the original sample. More thorough English-language reports about this project will appear in the series of research reports of the Institute of Education of the University of Helsinki. The first of these reports appeared in September, the second in October 1967. 
There is also evidence of considerable geographic mobility among the pupils in the last grade of Junior Secondary. $37 \%$ had changed their community of residence at least once, $29 \%$ had attended more than one primary school (normally 4 years) and $13 \%$ had attended more than one junior secondary school (normally 5 years). At the time of the study $22 \%$ of the subjects attended a secondary school in a community other than their home commune, $6 \%$ had to have a separate school residence and $9 \%$ used more than two hours daily for commuting to school.

The rapid expansion of secondary school education in Finland is mirrored in the fact that only $28 \%$ of the primary guardians of the pupils in the last grade of Junior Secondary School had themselves finished the Junior Secondary School, only $12 \%$ had finished the Senior Secondary School and only $7 \%$ had taken an academic degree. An interesting sex difference was that $75 \%$ of the girls' and $65 \%$ of the boys' primary guardians had only primary school education. Similarly, a greater proportion of the girls came from manual worker or farmer families, and a greater proportion of the boys from families with middle or upper class occupations.

In the year following the last grade of the Junior Secondary about one half, $51.5 \%$, of the Junior Secondary School graduates were attending the Senior Secondary School, $18.3 \%$ were repeating another year in the Junior Secondary School, and $30.2 \%$ had left the secondary school completely. Senior Secondary School attendance was both the most popular and the most easily attainable alternative, as $53 \%$ of the subjects had applied for it and $95 \%$ of those applying were actually studying there. On the other hand, only $13 \%$ of the subjects had applied for admittance to different kinds of vocational or technical schools, and only $53 \%$ of these or $7 \%$ of the total sample were in the following autumn (1965) actually studying at such schools.

Those Junior Secondary School graduates who had completely left the secondary school can be divided into four almost equal sized groups: a) those continuing studies at technical or vocational schools; b) those practicing in order to apply to the aforementioned schools; c) those working for wages; and, d) those who selected other alternatives, such as staying at home, being in military service, staying abroad, etc. These placements were, however, largely considered as temporary. When asked about their expectations for the following year, the subjects indicated many differing alternatives. Especially the proportion of those studying at technical and vocational schools was expected to double, while only a minority of those currently working for wages expected their actual work to be the beginning of a permanent occupation. How far these expectations were realized has not yet been ascertained.

The most popular alternative, the transfer to the Senior Secondary School correlated evidently with the previous school achievements of the subjects. The association was, however, not consistent, as about $22 \%$ of those among the lowest two fifths of achievement level continued their theoretical studies in Senior Secondary School, while about $13 \%$ of the subjects in the uppermost fifth of achievement level did not go on with these studies. A tendency to continue theoretical studies in spite of low achievement was especially characteristic of the boys. Future analysis will particulariy focus on comparing the achievement in Junior and Senior Secondary Schools in order to get information for future screening purposes.

It is interesting to note that about one fifth $(18 \%)$ of the students in the last grade of the Junior Secondary School did not leave this stage, but repeated the last grade for a second year of study. Moreover, the repeating of this last grade in the majority of the cases was quite intentional. It seems that the subjects used this as a device for getting a better graduation certificate from the Junior Secondary School, which would be useful for continuing in the Senior Secondary School or for applying to vocational or technical schools. There was also some evidence that some of those who transferred 
to the Senior Secondary School planned to use a year's study there as a similar device for getting to a vocational or technical school.

In summary the analysis of the preliminary descriptive data indicates 1) the great heterogeneity of background and past experience of the present Finnish Junior Secondary School graduates; 2) their mobility and vacillation in their decisions concerning the future; and 3 ) that individuals within a certain institutional system try to counteract in different ways the difficulties this system creates for them even by making choices and taking paths that are not intended by the system. In planning educational systems the occurrence and the consequences of this kind of individual behavior should be taken into account. 